\title{
Anlaşma Temeline Dayalı Boşanma Davalarında Hakimin Yoksulluk Nafakasına Müdahalesi
}

\author{
Nihan Koyuncu Aktaş* ${ }^{*}$
}

\section{Öz}

Anlaşma temeline dayalı boşanma davalarında tarafların boşanmasına karar verilebilmesi için taraflarca kabul edilen bir düzenlemenin mevcut olması gerekmektedir (TMK md 166/III). Taraflarca kabul edilen düzenleme ile eşler, boşanmanın mali sonuçları ve çocukların durumuna ilişkin anlaşmış olmalıdır. Bununla birlikte TMK md 166/III c 3 hükmünde yer alan bu düzenleme hakimin, taraflarca kabul edilen düzenlemede değişikliğe neden olabilecek müdahalesinin mümkün olduğunu işaret etmektedir. Çalışma konumuz olan ve boşanmanın mali sonuçları arasında yer alan yoksulluk nafakası da taraflarca kabul edilecek düzenlemenin zorunlu içeriğine dahildir. Bu kapsamda hakimin yoksulluk nafakasına müdahalesinin mümkün olduğu sonucuna varılmaktadır. Ne var ki yabancı hukuk sistemlerinde boşanma hukukundaki güncel değişiklikler hakimin boşanmanın mali sonuçlarına yönelik müdahalesinin sınırı tutulması yönündedir. Çocuğun durumuna ilişkin düzenlemelerin tersine, tarafların serbest tasarrufuna dahil olması nedeni ile yoksulluk nafakasına müdahalenin dar yorumlanması, olması gereken hukuk açısından yerindedir. Bununla birlikte tarafların yoksulluk nafakasına yönelik sözleşme serbestisinin sınırları mevcuttur. Gerçekten taraflar, sözleşmenin içeriğini belirlerken bu içeriğin kanunun emredici düzenlemelerine, kamu düzenine, kişilik haklarına uygunluğa ve konusunun imkansız olmamasına riayet etmekle yükümlüdür. Buna ilaveten Medeni Kanunun genel ve çerçeve nitelikli amir hükümleri de tarafların sözleşme özgürlüğünü sınırlamaktadır. Bu sınırlamalar hakimin yoksulluk nafakasına müdahalesinin kapsamını da belirlemektedir. Bu kapsamda öncelikle hakimin yoksulluk nafakasına ilişkin düzenlemenin geçerli olup olmadığını denetleme ödevi bulunduğu belirtilmelidir. Hakim, yoksulluk nafakası da dahil olmak üzere düzenlemenin zorunlu içeriğinin serbest bir irade ürünü olup olmadığını da incelemelidir. Bu belirtilenler kapsamında hakimin yoksulluk müdahalesinin kapsamı ve sınırları özellikle uygulamada karşıaşılan muhtemel problemlerle birlikte ele alınmaktadır. Tarafların yoksulluk nafakası hususunda sessiz kalması, yoksulluk nafakasını saklı tutması, nafakanın belirli bir süre için verileceği yönünde anlaşması, nafakadan feragat edilmesi ve nafaka miktarıın çok yüksek ya da çok düşük belirlenmesi gibi durumlarda hakimin müdahalesinin kapsamı ve sınırları değerlendirilmektedir.

\section{Anahtar Kelimeler}

Yoksulluk Nafakası, Boşanmanın Mali Sonuçları, Anlaşmalı Boşanma, Anlaşmalı Boşanma Protokolü, Hakimin Müdahalesi

\section{Alimony Scrutiny by Judge in Mutual Consent Divorces}

\section{Abstract}

According to Turkish Civil Code (TMK) Art 166/III, there shall be an agreement by the parties in order to place a judgement in a judicial divorce by mutual consent. The parties shall agree upon the financial consequences and a parenting plan, which constitute the mandatory scope of the agreement. TMK Art 166/III indicates that a judge may overrule stipulations in the agreement resulting in alterations. Therefore, scrutiny and alimony intervention, the subject of this study, is possible. Notably, current changes in foreign divorce law address limited scrutiny related to financial consequences. Unlike provisions related to the parenting plan, it is appropriate to restrict the extent of scrutiny on alimony since it is a matter the parties are free to decide. However, parties' freedom to the agreement has limitations. Parties shall guarantee that the content of agreement complies with the restrictive rules, public order, and personal rights. Freedom also has its 
limitations in the restrictive Civil Code rules that frame the extent of judge's scrutiny. Therefore, a judge shall examine the validity of provisions of the agreement and convinced that the provisions result from free will. Within the scope of the previously mentioned statements, the range and limits of scrutiny are discussed along with any possible disputes encountered in practice such as when parties are silent about the alimony, when alimony is reserved for further resolution, when alimony is limited to a specific time frame, when an alimony waiver has been declared, and when alimony is decidedly too high or too low.

Keywords

Alimony, Financial Consequences of Divorce, Divorce by Mutual Consent, Spousal Agreements, Judge's Scrutiny

\section{Extended Summary}

TMK Art 166/III regulates special grounds in mutual consent divorces. The Article mandates that with the presence of both parties' consensus (or acceptance of the claim by the other party) the marriage shall be deemed as it has been irretrievably broken. The presumption prohibits judges from making further examinations, such as if the marriage is in fact broken or if the parties have a fault. The judge shall pronounce the divorce if the Article's conditions are met.

One of the conditions is the judge's approval of the spousal agreement. Precisely, TMK Art 166/III requires that both spouses agree on the financial consequences of divorce and a parenting plan. Yet, this agreement alone does not enable a judge to decide on a judicial divorce. It must be approved by a judge. Therefore, both parties accept that a judge's scrutiny may result in alterations to the agreement. This phrase clarifies that a judge can propose necessary changes in the agreement. In this case, the divorce is pronounced only if the proposal is accepted by both parties. Otherwise, the action is dismissed and the Supreme Court considers it a contested divorce action.

In this study, the judge's scrutiny and intervention on alimony provisions is examined taking into consideration that divorcing parties reach a consensus on alimony as it is included in the mandatory content of the spousal agreements. To this end, the legal nature of spousal agreement is examined primarily. We conclude that spousal agreements are like a private-law contract with the similar character of a settlement agreement. The necessity of a judge's approval is not a constituent element but a complementary one. Thus, the legal nature of the agreement remains unchanged after it is approved by the court. In light of the conclusions mentioned, a judge's scrutiny of alimony provisions is critical since this area has the highest possible conflicts.

A judge's intervention is primarily required when the parties are silent about alimony in the spousal agreement. The same can be said when a provision is reserved for further resolution by the parties. A judge shall not approve any agreement that is silent about alimony as TMK Art 166/III only refers to agreements that include a 
consensus on the financial consequences of divorce and the parenting plan. The result is also the same when the parties reserve their rights to claim future alimony since this shows a non-consensus on alimony. Contrarily, it is considered as leaving the judge to decide the alimony solution is possible, as is the case with Swiss Civil Code (ZGB) Art 112, TMK Art 166/III, where there is no restraint to do so.

When the agreement includes a provision about alimony but not the ratio of change in the following years, it shall still be approved since the ratio of change is not mandatory content of the spousal agreement. Notably, most problems regarding alimony stem from the alimony waiver or when the amount is defined as too high or too low, in which case TMK Art 23 shall be decisive. 


\section{Anlaşma Temeline Dayalı Boşanma Davalarında}

\section{Hakimin Yoksulluk Nafakası Düzenlemesine Müdahalesi}

\section{Giriş}

Türk Medeni Kanununun ${ }^{1}$ 166/III fikrası ile evlilik birliğinin en az bir yıl sürmüş olması halinde eşlerin birlikte başvurması ya da bir eşin açtı̆̆ davayı diğer eşin kabul etmesi halinde evlilik birliğinin temelinden sarsılmış sayılacağı kabul edilmektedir.

TMK md 166/III hükmü uyarınca açılan davalar uygulamada ve Türk hukuk literatüründe anlaşma temeline dayalı boşanma davası (anlaşmalı boşanma davası) olarak adlandırılmaktadır ${ }^{2}$. Gerçekten bu halde eşler mahkemeye birlikte başvurmakta ya da bir eşin açtığ dava diğer eş tarafından kabul edilerek diğer boşanma sebeplerinden farklı olarak bir anlaşma zemini üzerinde mutabakata varılmaktadır³.

TMK md 166/III hükmü kapsamında anlaşmalı boşanmaya karar verilebilmesi için hakimin eşleri bizzat dinleyerek iradelerini serbestçe açıkladıklarına kanaat getirmesi ve taraflarca kabul edilecek düzenlemeyi uygun bulması gerekmektedir. Bu madde ile taraflar arasında boşanmanın mali sonuçları ve çocukların durumuna ilişkin kabul edilen bir düzenlemenin mevcut olması gerektiği düzenlenmektedir.

TMK md 166/III fikrası eşler arasındaki düzenlemenin iki temel zorunlu unsuru barındırması gerektiğini işaret etmektedir: Bunlardan ilki, çocuğun durumuna ilişkin anlaşmadır. Bu kapsamda eşlerin müşterek çocuğu varsa çocuğun velayetinin kime bırakılacağ1, iştirak nafakası ve velayetin bırakılmadığı eş ile çocuk arasındaki

Türk Medeni Kanunu, Kanun Numaras1: 4721, Kabul Tarihi: 22.11.2001, RG 8.12.2001/24607.

Bilge Öztan Aile Hukuku (6. Bası, Turhan Kitabevi, 2015) 692; Mustafa Dural, Tufan Öğüz ve Mustafa Alper Gümüş Türk Özel Hukuku Cilt III Aile Hukuku (Gözden Geçirilmiș 15. Bası Filiz Kitabevi, 2020) 123; Elçin Gülçin Grassinger 'Boşanma Davasında Eşlerin Boşanmanın Tali Sonuçlarına İlişskin Konularda Anlaşma Yapmaları ve Konu ile İlgili İsviçre Federal Mahkemesi Kararı' (1997) LV (3) İHFM 235, 237; Saibe Oktay Özdemir 'Türk Hukukunda Boşanma Sisteminde Revizyon İhtiyacı' (2015) 35 (1) MHB 29, 32. Sevtap Yücel 'Yargıtay Kararları Ișığında Anlașmalı Boşanma Davası Sonrasında Nafaka ve Tazminat Talepleri' (2018) 4 (1) 239, 240; Öz Seçer 'Anlaşmalı Boşanmada Eşlerin Yaptıkları Anlaşma' (2016) 7 (2) İnönü Üniversitesi Hukuk Fakültesi Dergisi 259, 260; Mine Uzun Yargıtay Kararları Kapsamında Yoksulluk Nafakası (Vedat Kitapçılık, 2013) 22.

3 Avrupa Birliği Aile Hukukunu uyumlaştırabilmek amacı ile kurulan Avrupa Birliği Aile Hukuku Komisyonu (CEFL) tarafından Avrupa Aile Hukuku Prensipleri (PEFL) oluşturulmuştur. Bu konuda bkz Şükran Şıpka 'Avrupa Birliği Aile Hukuku ve CEFL (Avrupa Birliği Aile Hukuku Komisyonu, Prensipleri, Amaçları ve Yapılan Çalışmalar)’ (2006) 10(2)163, $165 \mathrm{vd}$. PEFL düzenlemesinde boşanma sebepleri, tarafların ortak rızasına dayalı anlaşmalı boşanma ve diğer eşin rızası olmaksızın boşanma olmak üzere iki gruba ayrılmaktadır Anlaşmalı boşanmayı düzenleyen PEFL 1:4 maddesinde iki tarafın anlaşması ile boşanmaya karar verileceği düzenlenmektedir. Bununla birlikte eşlerin, on altı yaşının altında çocukları varsa ve boşanmanın sonuçlarına ilişkin PEFL 1:6 düzenlemesinde yer alan anlaşmaya varmışlarsa üç aylık düşünme süresi gerektiği ayrıca düzenlenmektedir (PEFL 1:5(1)). Boşanmanın sonuçları üzerinde anlaşmaya varılmamışsa düşünme süresi altı aydır (PEFL 1:5(1)). Eşlerin çocukları yoksa ve malların paylaşımı ile boşanma sonrası nafaka hususunda anlaşmaya varmışlarsa düşünme süresi uygulanmaz; ancak anlaşmaya varılmamışsa üç aylık düşünme süresi geçerlidir (PEFL 1:5(2)). PEFL 1:6(1) hükmünde ise anlaşmanın içeriği düzenlenmektedir. Buna göre eşler (a) velayet hakkı ve gerekli olması halinde çocuğun oturacağı yer ve çocukla ilișki kurulması (b) çocuk yararına nafaka (c) malların paylașılması (d) boșanma sonrası nafaka hakkında anlaşabilir. Bkz Şıpka (n 3) 166 vd; Philipp Bauermann Grundlagen und Ausgestaltung im deutschen Unterhaltsrecht und in den Prinzipien der Commission on European Family Law (CEFL) (Stämpfli Verlag AG, 2013) §13 N 236; Marianne Roth, 'Future Divorce Law- Two Types of Divorce' (2005) Common Core and Better Law in European Family Law 41, 43. 
kişisel ilişki temini hususunda anlaşmaya varılması zorunludur. İkinci zorunlu unsur ise tarafların boşanmanın mali sonuçları yönündeki mutabakatıdır. Bu kapsamda tarafların yoksulluk nafakası ile maddi ve manevi tazminatı kapsayan mali sonuçlar hususunda da anlaşması gerekmektedir'.

Belirtmemiz gerekir ki eşler, TMK md 166/III hükmünde belirtilen zorunlu unsurlar ile yetinmeyip aile konutu ya da mal rejiminin tasfiyesi gibi esasen ihtiyari olan hususlarda da anlaşmaya varabilir. Şu halde TMK md 166/III’te yer alan zorunlu unsurlar ve eşler tarafından görüşmelere taşınması nedeniyle sübjektif esaslı unsur haline getirilen ihtiyari hususlar üzerinde mutabakata varılması zorunludur. Ne var ki bu mutabakat boşanmak için yeterli değildir. Hakimin, eşler arasında boşanmanın mali sonuçları ve çocukların durumuna ilişkin yapılan düzenlemeyi uygun bulması ve iradelerini serbestçe açıkladıklarına kanaat getirmesi gerekmektedir ${ }^{5}$. Zira TMK md 166/III fikrası ile hakimin tarafların ve çocukların menfaatini göz önünde bulundurarak bu anlaşmada gerekli gördüğü değişikleri yapma hususunda takdir yetkisi olduğu düzenlenmektedir. Diğer bir ifade ile hakimin, eşler arasında yapılan düzenlemeye müdahale ${ }^{6}$ edebileceği işaret edilmektedir. Bu kapsamda çalışmamızda boşanmanın mali sonuçlarından olan yoksulluk nafakasına hakimin müdahalesinin sınırlarının tartışılması amaçlanmaktadır. Bu tartışmalar, TMK md 166/III hükmü uyarınca açılan anlaşma temeline dayalı boşanma davaları ile sınırlandırılmaktadır.

Uygulamada TMK md 166/III hükmü kapsamında açılan boşanma davalarında genellikle tarafların imzasını taşıyan düzenlemenin dava dilekçesine eklenerek mahkemeye sunulması yoluyla dava açıldığı görülmektedir. Anlaşmalı boşanma protokolü7 olarak adlandırılan bu düzenlemede çoğunlukla çocukların durumu ve boşanmanın mali sonuçlarına ilişkin taraf iradeleri yer almaktadır. Ancak bu durum her zaman böyle olmayabilir. Esasen hakim tarafından uygun bulunmaması gereken bir düzenleme boşanma davasının kabul edilmesini takiben şeklen kesinleşmiş olabilir. Gerçekten anlaşmalı boşanma davaları kabul edilen ve dolayısıyla bir anlaşmaya varmış tarafların bu kararı temyiz etmesi pek sık karşılaşılan bir durum değildir. Aksine taraflar çoğunlukla temyizden feragat ederek boşanma kararının hızlıca kesinleşmesini amaçlamaktadır. Bunun doğal (ve olması gereken) sonucu, hakim tarafından uygun görülerek onaylanmış düzenlemelerin denetimden mahrum olmasıdır. Bununla birlikte tarafların, boşanma kararının kesinleşmesinden sonraki

\footnotetext{
Elçin Grassinger (n 2) 235, 236; Ebru Ceylan, Türk ve İsviçre Hukukunda Boşanmanın Hukuki Sonuçları (Galatasaray Üniversitesi Yayınları, 2006) 126; Seçer (n 2) 259, 263.

TMK md 166/III, c 2 .

Müdahale ifadesi ile hakimin taraflar arasında kabul edilen sözleşmede, sözleşmenin tamamlanması da dahil olmak üzere herhangi bir değişiklik yapılması sonucunu doğuracak işlem ve önerileri aktarılmaktadır. Hakimin müdahalesi, hakime TMK md 166/III hükmü ile yüklenen denetim ödevinin sonucudur.

Bu ifadeye yer veren kararlar için bkz Yargıtay 3 HD, 448/19024, 26.11.2015; Yargıtay 2 HD, 4268/6909, 10.6.2019; Yargitay 12 HD, 5762/2780, 25.2.2019 vb. Yargitay'ın daha eski kararlarında bu kavram ile aynı anlama gelmek üzere mali proje ifadesinin kullanıldı̆̆ görülmektedir. Bu yöndeki kararları için bkz Yargıtay 2 HD, 10499/14491, 21.11.1991; Yargıtay 2 HD, 12452/12840, 21.12.1994 (Lexpera <lexpera.com.tr> Erişim Tarihi 10 Eylül 2020).
} 
süreçte anlaşmalı boşanma protokolünde yer alan bazı düzenlemelerin hukuka aykırılığını ileri sürmesi mümkündür. İşte bu gibi hallerde taraflar arasındaki düzenlemeyi inceleyen Bölge Adliye Mahkemeleri veya Yargitay, yerel mahkeme hakimi tarafından bu düzenlemenin uygun görülmeyerek değişiklik yapılmış olması gerektiği yönünde karar verebilmektedir. Örneğin, velayetin birakılmadığı eş (baba) ile çocuk arasında on sekiz yaşını bitirinceye kadar internet, telefon veya sair olanakları kullanarak iletişim kurulmayacağı yönündeki düzenlemeye yerel mahkeme safhasında müdahale edilmiş olması gerektiği yönünde karar verilmiştir Burada hemen belirtmek gerekir ki Yargıtay kararına konu olayda çocuğun durumunu ilgilendirmesi nedeniyle kamu düzenine ilişkin olan düzenlemeye müdahale edilmiş olması gerektiği tartışmasızdır. Çalışma konumuz olan yoksulluk nafakası ise boşanmanın mali sonuçlarına dahildir. Bu kapsamda yoksulluk nafakasına ilişkin düzenlemelerde hakimin müdahalesinin sınırları tartışma konusu olabilecektir. $\mathrm{Bu}$ bağlamda, örneğin, taraflarca kabul edilen düzenlemede eşler yoksulluk nafakasına ilişkin sessiz kalmış ya da yoksulluk nafakası hususunda çözümü hakime bırakmış olabilir. İlk halde hakimin, tarafların yoksulluk nafakası hususunda anlaşmaya varması gerektiği yönünde müdahale mi edeceği yoksa taleple bağl1lık gereği bu hali ile protokolü tasdik mi edeceği tartışılmalıdır. Yoksulluk nafakası meselesinin çözümünün hakime bırakıldığı ikinci örnekte ise, ZGB Art 112'de düzenlenen kısmi anlaşmalı boşanmaya Türk hukukunda cevaz verilip verilmediği tartışılmalıdır. Ne var ki yoksulluk nafakası ile ilgili muhtemel uyuşmazlıklar bu sayılanlarla sınırlı değildir. Çok yüksek veya çok düşük yoksulluk nafakası düzenlemesine yer verilmesi, yoksulluk nafakasının belirli bir süre için ödeneceği hususunun kabul edilmesi, yoksulluk nafakasından açık ya da örtülü feragat edilmesine rağmen sonradan talep edilmesi halinde hakimin bu talebi kabul etmesi gerekip gerekmediği hemen olumlu ya da olumsuz cevap verilebilecek hususlar değildir. Türk Medeni Kanunumuzun işaret ettiği kavramsal sınırı ile insan onuru boyutunda ele alınması gerektiğini düşündüğümüz yoksulluk nafakası hususunda nafakadan feragat ${ }^{9}$ meselesi dahi üzerinde tekrar durulması gereken konulardan biridir. Bu amaçla TMK md 166/III hükmünde yer alan düzenlemenin hukuki niteliği ve anlaşma temeline dayalı boşanma davası hakkındaki açıklamalarımızı takiben bu olası problemlere yer verilmektedir.

\section{TMK md 166/III Hükmünde Yer Alan}

\section{Düzenlemenin Hukuki Niteliği}

TMK md 166/III, c 1 ve 2 şöyledir: "Evlilik en az bir yıl sürmüş ise, eşlerin birlikte başvurması ya da bir eşin diğerinin davasını kabul etmesi hâlinde, evlilik birliği

Yargıtay 2 HD, 11644/1866, 4.2.2014 (Kazancı İçtihat Bankası <www.kazancı.com.tr> Erişim Tarihi 17 Temmuz 2020$)$.

Anlaşmalı boşanma protokolünde yoksulluk nafakasından açıkça feragat eden tarafın daha sonra nafaka talep edemeyeceği hususu doktrinde oybirliği ile kabul edilmektedir. Yargıtay kararları da bu yöndedir. Buna ilişkin görüşler ve açıklamalarımız için bkz aşa $\mathrm{V}, 4$. 
temelinden sarsılmış sayılır. Bu hâlde boşanma kararı verilebilmesi için, hâkimin tarafları bizzat dinleyerek iradelerinin serbestçe açıklandığına kanaat getirmesi ve boşanmanın malî sonuçları ile çocukların durumu hususunda taraflarca kabul edilecek düzenlemeyi uygun bulması şarttır.

Madde metninden görüleceği üzere anlaşma temeline dayalı boşanma davalarında tarafların boşanmanın mali sonuçları ve çocukların durumuna ilişkin anlaşmaya varmış olması şarttır ${ }^{10}$. Her ne kadar madde metninde bu durumu işaret etmek amacı ile düzenleme ifadesi tercih edilmişse de anlaşmanın geçerliliği yazılı olmasına bağlı değildir ${ }^{11}$. Aksine taraflarca sözlü olarak da anlaşmaya varılabilir ${ }^{12}$. Önemli olan taraflar arasındaki sözlü anlaşmanın imzaları alınmak kaydı ile duruşma esnasında tutanağa geçirilmesi ve anlaşmanın boşanma hükmünde yer almasıdır ${ }^{13}$. Uygulamada ise taraflar çoğunlukla yazılı bir düzenlemeyi tercih etmekte ve bu düzenlemeyi dava dilekçesinin eki ile mahkemeye sunmaktadır. Anlaşmalı boşanma protokolü olarak adlandırılan bu düzenlemenin ya da taraflarca sözlü olarak varılan anlaşmanın hukuki niteliği tartışılmaktadır.

$\mathrm{Bu}$ konuda doktrinde ileri sürülen bir görüşe ${ }^{14}$ göre boşanmanın mali sonuçları ve çocukların durumuna ilişkin taraflarca kabul edilen düzenleme, taraflarca birlikte ileri sürülen talep niteliğindedir. Bu görüşe göre eşlerin birbirine karşı değil mahkemeye birlikte yönelttiği bir talep söz konusudur. Bu nedenle bu talebin dava dışı hukuki bir değeri mevcut değildir.

Doktrinde ileri sürülen çoğunluk görüşe göre ise burada bir sözleşme ilişkisi mevcuttur. TMK md 166/III hükmünde işaret edilen düzenlemenin sözleşme

10 TMK md 166/III'te ișaret edilen anlaşmaya benzeyen bir bașka düzenleme TMK md 184/V'de yer almaktadır. TMK md 184/V fikrası uyarınca boşanma veya ayrılığın fer'i sonuçlarına ilişkin anlaşmalar, hakim tarafından onaylanmadıkça geçerli olmaz. Durum böyleyken TMK md 166/III hükmünde yer alan, boşanmanın mali sonuçları ve çocukların durumuna ilişkin düzenleme ile TMK md 184/V'de yer alan boşanmanın feri sonuçlarına ilişsin anlaşma birbirinden farklıdır. TMK md 166/III hükmünde işaret edilen taraflarca kabul edilen düzenlemenin mevcudiyeti anlaşma temeline dayalı boşanma davasının kabul edilmesi için zorunludur. TMK md 184/V'te işaret edilen anlaşma ise anlaşmalı boşanma davaları dışında kalan ve çekişmeli yargıda dava yolu ile görülen boşanma davalarında anlaşmaya varılması halinde bu anlaşmanın hakim tarafından onaylanmadıkça geçerli olmayacağını düzenlemektedir. Şu halde taraflar çekişmeli yargıda dava yolu ile görülen bir boşanma davasında da anlaşmaya varabilir. Hal böyleyken burada bir zorunluluk yoktur. Bu şekilde bir anlaşma yapılmamış olsa dahi hakim, gerekli incelemeleri takiben boşanma kararı verebilir. Halbuki anlaşma temeline dayalı boşanma davalarında taraflar arasında boşanmanın mali sonuçları ve çocukların durumuna ilişkin bir anlaşmanın bulunması zorunludur. Aksi halde anlaşma sağlanamadığından davanın reddi gerekmektedir. TMK md 166/III ve TMK md 184/V düzenlemelerinin farkı ve hukuki nitelikleri hakkında ayrıntılı bilgi için bkz Turhan Esener, 'Boşanmanın Fer'i Neticelerine Dair Mukaveleler' (1951) VIII (3-4) AÜHFD 610, 620; Elçin Grassinger (n 2) 235, 236; Nevzat Özdemir, Türk Hukukunda Anlaşmalı Boşanma (İstanbul Üniversitesi Sosyal Bilimler Enstitüsü, Yayımlanmamış Doktora Tezi, 2003$) 190$.

11 Dural, Öğüz ve Gümüş (n 2) 125. ZPO Art 130 hükmü uyarınca sözleşmenin yazılı olması gerektiği yönünde: Alexandra Jungo, Personen- und Familienrecht - Partnerschaftsgesetz Art. 1-456 ZGB - PartG, Handkommentar zum Schweizer Privatrecht (3. Bask1, Schulthess Juristische Medien AG, 2016) Art 111 N 6. PEFL 1:6 (2) düzenlemesinde de bu sözleşmenin yazılı şekilde yapılması gerektiği açıkça düzenlenmektedir.

12 Taraflar arasındaki düzenleme duruşma esnasında ve hakimin desteği ile olușturulmaktaysa burada tarafların olgun iradesinin ürünü olan bir anlaşmadan söz etmek uygun olmaz meğer ki tarafların daha önceden serbest ve olgun iradeleri ile sözlü olarak anlaştıkları hususlar tutanağa geçiriliyor olsun (Bu konuda bkz Roland Fankhauser, Die Ehescheidung und die Ehetrennung / Erster Abschnitt: Die Scheidungsvoraussetzungen, FamKomm (3. Bask1, Stämpfli Verlag AG, 2017) ZGB $111 \mathrm{~N} 11$ ).

13 Hukuk Muhakemeleri Kanunu, Kanun Numaras1: 6100, Kabul Tarihi: 12.1.2011, RG 4.2.2011/27836. HMK md 154 (3) ç.

14 Esat Arsebük, Medeni Hukuk II Aile Hukuku Kısım 1 (1940) 767. 
niteliğinde olduğunu belirten bir grup yazar burada özel hukuka tabi bir sözleşme olduğunu belirtmektedir ${ }^{15}$. Bu sözleşmenin bazı farklılıklar haricinde sulh sözleşmesine benzediği de doktrinde ileri sürülmektedir ${ }^{16}$. Bununla birlikte taraflar arasındaki düzenlemenin kendine özgü bir aile hukuku sözleşmesi olduğu da doktrinde yer alan görüşler arasındadır ${ }^{17}$. Yargıtay kararları incelendiğindeyse taraflar arasındaki düzenlemenin özel hukuk sözleşmesi niteliğinde olduğu ${ }^{18}$, kendine özgü sözleşme niteliğinde olduğ $\mathrm{u}^{19}$, sulh sözleşmesi niteliğinde olduğ ${ }^{20}$ yönünde farkl1 kararlarının mevcut olduğu görülmektedir.

Taraflar arasında kabul edilen düzenlemenin hakim tarafından onaylanmasından sonraki niteliği hususunda da iki farklı temel görüş mevcuttur. İlk görüşe göre hakimin onayı ile birlikte düzenleme özel hukuk sözleşmesi niteliğini yitirerek artık boşanma kararının bir parçası olur ${ }^{21}$. İkinci görüşe göre ise hakimin onayı özel hukuk sözleşmesi niteliğinde olan düzenlemenin hukuki niteliğini değiştirmemektedir ${ }^{22}$.

Biz bu konuda, TMK md 166/III hükmünde yer alan boşanmanın mali sonuçları ile çocukların durumuna ilişkin taraflarca kabul edilecek düzenlemenin tarafların karşılıklı ve birbirine uygun irade beyanlarını içermesi nedeni ile özel hukuk sözleşmesi niteliğinde olduğu yönündeki çoğunluk görüşe katılmaktayız. Gerçekten bu düzenleme ile taraflar boşanmanın mali sonuçlarına ilişkin hususlarda serbestçe karar vererek bu hususlara ilişkin uyuşmazlığı kendi aralarında yaptıkları anlaşma uyarınca çözmek istemektedir. Kanun koyucu da tarafların bu yöndeki iradesini dikkate almaktadır ${ }^{23}$. Bu kapsamda taraflarca kabul edilen düzenlemelerin maddi hukuka ilişkin anlaşmalar olmasının yanı sıra niteliği itibari ile mahkeme içi sulh

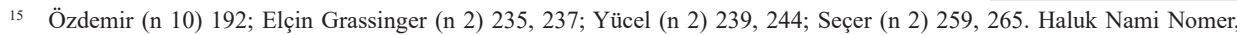
Borçlar Hukuku Genel Hükümler (Gözden Geçirilmiş, Genişletilmiş Ondördüncü Baskı, Beta, 2015) 55; Yücel (n 2) 239, 244. TMK md184/V hükmü açısından Kemal Oğuzman ve Turgut Öz, Borçlar Hukuku Genel Hükümler Cilt-1 (Güncellenip Genişletilmiş 17. Bası Vedat Kitapçılık, 2019) 178. Ayrıca bkz Turgut Akıntürk ve Derya Ateş, Türk Medeni Hukuku Aile Hukuku İkinci Cilt (Yenilenmiş 21. Bas1, Beta, 2019) 271. İsviçre hukukunda bu yönde: Jungo (n 11) Art 111 N 12.

16 Walter Bühler ve Karl Spühler, Berner Kommentar, Die Ehescheidung, Art. 137-158 ZGB, Schweizerisches Zivilgesetzbuch Das Familienrecht, Das Eherecht, (3. Bask1, Stämpfli Verlag AG, 1980) Art 158 N 172; Esener (n 10) 610, 612-613; Mustafa Tolga Özer, Medeni Hukukta Hata Kavramı (On iki Levha, 2019) 324. Ayrıca bkz Özkan Cavit Hoşlan 'Anlaşmalı Boşanma Protokollerine İlişkin Yargıtay Kararlarının Değerlendirilmesi’ Medeni Hukuk Alanındaki Güncel Yargıtay Kararlarının Değerlendirilmesi Sempozyumları, Cilt II: Aile Hukuku (On iki Levha, 2019) 203, 224.

17 Hande Ülkü Atmaca, Türk Hukukunda Anlaşmalı Boşanma Protokolü (Yeditepe Üniversitesi Sosyal Bilimler Enstitüsü, Yayımlanmamış Doktora Tezi, 2017) 74vd.

18 Yargıtay 3 HD, 19608/23901, 20.11.2012 (Kazancı İçtihat Bankası<www.kazancı.com.tr> Erişim Tarihi 12 Mayıs 2020).

19 Yargıtay Hukuk Genel Kurulu Kararı, 2-1895/630, 30.5.2019 (Kazancı İçtihat Bankası <www.kazancı.com.tr> Erişim Tarihi 12 Mayıs 2020).

20 Yargıtay Hukuk Genel Kurulu Kararı, 2-1941/475, 18.4.2019 (Kazancı İçtihat Bankası <www.kazancı.com.tr> Erişim Tarihi 13 Mayıs 2020).

21 Bühler ve Spühler (n 16) Art 158 N 172; Esener (n 10) 610, 613.

22 Özer (n 16) 322.

23 Özer (n 16) 321. 
sözleşmesi karakterini haiz olduğu da değerlendirilebilecektir ${ }^{24}$. Bu değerlendirmenin sonucunda anlaşmalı boşanma protokolünde yer alan yoksulluk nafakasının hata nedeniyle iptal edilip edilemeyeceği aşağıda ayrıca tartışılmaktadır ${ }^{25}$.

Medeni Kanunumuz tarafların boşanmanın mali sonuçları ve çocuğun durumuna ilişkin anlaşmasını şart koşmakla birlikte bu anlaşmanın boşanma kararı verilmesi için yeterli olmadığını işaret etmektedir. Boşanma kararı verilmesi, taraflarca kabul edilen düzenlemenin hakim tarafından uygun görülmesine bağlıdır ${ }^{26}$.

TMK md 166/III hükmünde taraflarca kabul edilen düzenlemenin hakim tarafindan uygun bulunması şartına yer verildiğinden hakimin onayının sözleşmeye etkisi incelenmelidir. Kanaatimizce burada hakimin onayından önce tarafların karşılıklı ve birbirine uygun irade beyanı ile kurulmuş bir sözleşme mevcuttur. Tarafların karşılıklı ve birbirine uygun irade beyanlarının mevcudiyeti sözleşmenin kurulması için gerekli ve yeterlidir. Hakimin taraflarca kabul edilen düzenlemeyi uygun görmesi şeklinde tezahür eden resmi makamın fiili taraflar arasındaki sözleşmenin kurucu unsuru değil hüküm ifade etmesi için gerekli tamamlayıcı unsurudur ${ }^{27}$. Bu kapsamda hakimin onayından önce de taraflar arasında kurulmuş bir sözleşme mevcuttur ${ }^{28}$.

Esasen burada sözleşmenin hükümlerinin doğurmasının değil de boşanma kararının verilmesinin hakim tarafından sözleşmenin uygun görülmesine bağlı olduğu ve sözleşmenin kurulduğu andan itibaren hüküm ifade edeceği belirtilebilir. Ne var ki sözleşmenin içeriği olan çocukların durumu ve mali sonuçlar boşanmaya

24 Bu yönde Bühler ve Spühler (n 16) Art 158 N 172; Özer (n 16) 324. Tarafların, nafaka ve tazminat gibi üzerinde serbestçe tasarruf edebileceği içeriğinin sulh sözleşmesi niteliğinde olduğu yönünde Hoşlan (n 16) 203, 224. HMK md 313 (1): "Sulh, görülmekte olan bir davada, tarafların aralarındaki uyuşmazlığ kısmen veya tamamen sona erdirmek amacıyla, mahkeme huzurunda yapmış oldukları bir sözleşmedir."

25. Bkz aşa $\mathrm{V}, 4$.

26 TMK md 166/III, c 2 .

27 Kurucu unsur olduğu yönünde Elçin Grassinger (n 2) 236-237. Hakimin onayını tamamlayıcı unsur olarak arayan görüş için bkz Nomer (n 15) 55; Yücel (n 2) 239, 244; Hoşlan (n 16) 203, 224. TMK md 184/V hükmü açısından Oğuzman ve Öz (n 15) 178. Ayrıca bkz Akıntürk ve Ateş (n 15) 271. Tamamlayıcı unsur kavramı için bkz Nomer (n 15) 53-56; Oğuzman ve Öz (n 15) 177-181.

281 Şubat 2010 yürürlük tarihli değişiklik öncesinde ZGB Art 111/II hükmünde hakim tarafından anlaşmanın uygun olduğuna karar verilmesini takiben taraflara iki ay düşünme süresi tanınmaktaydı. Bu düşünme süresi bitiminde eşlerin boşanma iradelerinin devam etmesi ve anlaşmayı yazılı olarak onaylamaları halinde boşanmaya karar verilmekteydi. Düşünme süresinin düzenleniş amacından hareketle anlaşmadan her zaman serbestçe dönülebileceği ve anlaşmanın yazılı onay anına kadar tarafları bağlamadığı görüșü ileri sürülmekteydi (Doktrinde yer alan görüşler için bkz Jungo (n 11) Art 111, N 20. Ayrıca bkz BGE 135 III 193 E 2.2) Yeni düzenlemede taraflara anlaşmalı boşanma davalarında düşünme süreleri tanınmamıştır. Taraflar arasındaki sözleşmenin diğer sözleşmeler gibi kurulmasıyla birlikte bağlayıcı olduğu yönünde bkz Jungo (n 11) Art 111, N 21. Bu görüş Türk hukukunda da savunulmaktadır. Buna göre taraflar tek taraflı olarak sözleşmeden dönememeli ve hakimin sözleşmeyi onaylamasını engelleyememelidir. Bununla birlikte irade sakatlığı gibi hallerde tarafların hakimden sözleşmenin onaylanmamasını isteme hakkı olduğu belirtilmektedir (Bu yönde Esener (n 10) 615; Selahattin Sulhi Tekinay, Türk Aile Hukuku (7. Bask1, Filiz Kitabevi, 1990) 287; Özer (n 16) 324). Doktrinde ileri sürülen ve bizim de katıldığımız diğer görüş ise hakim onayına kadar sözleşmeden dönmenin mümkün olduğu yönündedir. Hakimin sözleşmeyi uygun bulması şartının, tarafların sözleşme ile bağlı olmadığı anlamına gelmediği; ancak TMK md 166/III hükmünde yer alan ve tarafların serbest iradesinin esas alınacağına ilişkin düzenlemenin belirleyici olduğu belirtilmektedir. Gerçekten taraf iradelerinin serbestçe açıklanmış olması özel önemi haizdir (Hoşlan n 16). Bu koşul hakime tarafların iradesinin sakatlanmış olup olmadığına kanaat getirmenin yanı sıra tarafların, taraflarca kabul edilen düzenleme çerçevesinde boşanma iradesinin devam edip etmediğini inceleme ödevi de yüklemektedir. Aksi düşünüldüğünde hakimin onay koşulu anlamsız kalacaktır. Bu yönde Özdemir (n 10). 
bağlı olan ve ancak boşanma kararı ile etkili hale gelecek sonuçlardır. Bu bağlamda ele alındığında da boşanma kararı verilmeden sözleşmenin hüküm doğurmayacağı (etkili hale gelmeyeceği) sonucuna varmak gerekir. Onayla birlikte taraflarca kabul edilen düzenleme mahkeme ilamının parçası haline gelirse de bu durum bu düzenlemenin özel hukuk sözleşmesi niteliğini etkilememektedir. Yasal temsilcinin sınırlı ehliyetsizin yaptığı işleme onay vermesinde olduğu gibi hakim tarafindan verilen onay da sözleşmenin niteliğini değiştirmeyecektir ${ }^{29}$.

Belirtmemiz gerekir ki, özel hukuk sözleşmesi niteliğinde olan bu düzenlemede taraflar yoksulluk nafakası hususunda sözleşme özgürlüğü çerçevesinde serbestçe uzlaşmaya varabilir. Ancak sözleşme özgürlüğünün sınırları mevcuttur. Tarafların sözleşme özgürlüğünün doğrudan sınırlaması niteliğinde olan TBK md 27 hükmünün yanı sıra Medeni Kanundaki genel ve çerçeve normlardan da sınırlama doğabilmektedir ${ }^{30}$. TBK md 27 hükmüne ya da sınırlama getiren diğer amir hükümlere aykırı olması nedeni ile kesin hükümsüz olan bir sözleşme, hakim tarafından uygun görülse dahi geçersizliğini korur. Zira tamamlayıcı unsur olan resmi makamın fiili geçerlilik şartlarını taşımayan bir sözleşmeye hüküm kazandırma işlevine sahip değildir ${ }^{31}$. Bu yüzdendir ki taraflar arasında kabul edilen ve hakim tarafindan uygun bulunan bazı düzenlemelerin hukuka aykırı olduğu iddiası ile sonradan dava açılması ile karşılaşılmaktadır. Tarafların mali durumlarının değişmesi gibi değişen şartlara uyarlanması haricinde kalan ve aslında kesin hükümsüz bir sözleşmenin hakim tarafından gerekli inceleme yapılmaksızın tasdik edilmiş olması nedeni ile açılan davaların önüne geçilmesi mümkündür. Nitekim TMK md 166/III hükmünde hakime yüklenen bir ödev söz konusudur: Hakim, taraflar arasında kabul edilen düzenlemeyi, tarafların ve çocuğun menfaati açısından incelemeli ve gerekli görmesi halinde değişiklik yapmalıdır ${ }^{32}$. Bununla birlikte boşanma hukukundaki güncel eğilimin boşanmanın mali sonuçlarına yönelik anlaşmalar hususunda hakime sınırlı bir müdahale yetkisi tanımaktan yana olduğu belirtilmelidir ${ }^{33}$. Gerçekten tarafların üzerinde serbestçe tasarruf edebileceği mali sonuçları borçlar hukukuna hakim ilkeler doğrultusunda özgürce düzenlemeleri esastır ${ }^{34}$. Çocukların durumu gibi kamu düzenini ilgilendirmesi sebebi ile serbestçe tasarrufa konu olmayan hususlarda ise hakimin müdahalesinin kapsamı daha geniş tutulmaktadır.

\footnotetext{
29 Özer (n 16) 322. Tamamlayıcı unsurun gerçekleşmesi ile birlikte sözleşmenin başlangıçtan itibaren değil resmi makamın fiilinden itibaren hüküm ifade edeceği belirtilmelidir. Aynı yönde Hoşlan (n 16) 203, 224.

30 Saibe Oktay Özdemir, “Sözleşme Özgürlüğü” (2019) 1 İstanbul Şerhi Türk Borçlar Kanunu: Yürürlük Kanunu Madde 1-82 337, 369.

31 Barış Demirsatan, 'Boşanmada Ev Hayvanlarının Hukuki Durumu' (2020) 24 (3) Ankara Hacı Bayram Veli Üniversitesi Hukuk Fakültesi Dergisi 137, 146.

32 TMK md 166/III, c 2 ve c 3.

33 Bu konuda bkz așa $\mathrm{V}$.

34 Özer (n 16) 322.
} 


\section{Anlaşma Temeline Dayalı}

\section{Boşanma Davalarında Evlilik Birliğinin}

\section{Sarsıldığı Faraziyesi ve Bu Faraziyenin Yoksulluk Nafakası ile İlişsisi}

TMK md 166/I hükmü ile evlilik birliğinin ortak hayatı sürdürmeleri kendilerinden beklenmeyecek derecede temelinden sarsılmış olması halinde eşlerden her birinin boşanma davası açabileceği düzenlenmektedir. $\mathrm{Bu}$ fıkrada, evlilik birliğinin temelinden sarsılmasına dayalı genel bir boşanma davası sebebi bulunmaktadır ${ }^{35}$.

TMK md 166/III hükmünde ise en az bir yıl süren evliliklerde eşlerin birlikte başvurması ya da bir eşin diğerinin davasını kabul etmesi halinde evlilik birliğinin temelinden sarsılmış sayılacağ 1 kabul edilmektedir ${ }^{36}$. Bu fikrada, belirli koşulların meydana gelmesi halinde evlilik birliğinin sarsıldığının kabul edileceği düzenlenmektedir. Bu koşullar, evlilik birliğinin en az bir yıl sürmüş olması ve eşlerin ya birlikte başvurmas1 ya da bir eşin açtı̆̆ davanın diğer eş tarafından kabul edilmesidir. Bu koşulların sağlanması ile artık evlilik birliğinin temelinden sarsıldığı kabul edildiğinden burada bir faraziye olduğu hususunda doktrinde görüş birliği mevcuttur ${ }^{37}$. Hakim, eşlerin en az bir yıl süreden beri evli olması ve birlikte başvurması ya da bir eş tarafından açılan davanın diğer eş tarafından kabul edilmesi halinde evlilik birliğinin temelinden sarsıldığını kabul etmekle yükümlüdür.

Belirtmemiz gerekir ki, TMK md 166/III hükmünde yer alan bu faraziye hakimin kusur araştırması yapmasını engeller ${ }^{38}$. Zira TMK md 166/III hükmünde yer alan düzenlemede evlilik birliğinin temelinden sarsılmış sayılması için taraflardan birinin kusurlu olması ya da her ikisinin kusursuz olması gibi bir koşul aranmamaktadır. Bu nedenle hakim, TMK md 166/III hükmü uyarınca açılan anlaşma temeline dayalı boşanma davalarında evlilik birliğinin temelinden sarsılıp sarsılmadığı hususunda taraflardan birinin kusurunun bulunup bulunmadığını araştıramaz. Hatta eşler arasındaki evlilik birliği temelinden sarsılmamış olsa dahi TMK md 166/III’te yer

35 Dural, Öğüz ve Gümüș (n 2) 118; Öztan (n 2) 678.

36 Ortak talebe dayalı boşanma mehaz ZGB Art 111-112 hükmünde düzenlenmektedir. ZGB Art 111 hükmünde tam anlaşmalı boşanma, ZGB Art 112 hükmünde ise kısmi anlaşmalı boşanmaya ilişkin düzenleme yer almaktadır. ZGB Art 111 hükmü ile eşlerin birlikte başvurarak boşanmanın sonuçlarına ve çocuklara ilişkin kapsamlı bir anlaşma ile gerekli belgeleri mahkemeye sunması halinde mahkemenin tarafları birlikte ve ayrı ayrı dinleyeceğini düzenlemektedir. Mahkeme, boşanma isteminin ve anlaşmanın tarafların serbest iradesinin ürünü olduğuna kanaat getirir ve çocuklara ilişkin düzenlemeyi onaylarsa boşanmaya karar verir (ZGB Art 111/II). Madde metninde ve ZPO Art 285 hükmünde açıkça ortak başvurudan söz edilmesine rağmen tarafların ortak boşanma iradesi mevcut olması kaydıyla ayrı ayrı başvurabileceği yönünde: Jungo (n 11) Art 111 N 10; Fankhauser (n 12) ZGB Art 111, N 9. ZGB Art 112 hükmünde düzenlenen kısmi anlaşmalı boșanma ise eşlerin boşanma hususunda anlaşmaya varmışken boşanmanın sonuçlarına ilişkin çözümü mahkemeye bırakması halini düzenlemektedir. Alman hukukunda da bir yıldır ayrı yașamakta olan eșlerin birlikte bașvurması ya da biri tarafından açılan davanın diğer eş tarafından kabul edilmesi halinde evlilik birliğinin sarsıldığı aksi ispatlanamaz şekilde kabul edilmektedir BGB $§ 1566(1)$.

37 Tekinay (n 28) 195; Akıntürk ve Ateş (n 15) 269; Dural, Öğüz ve Gümüş (n 2) 123; Öztan (n 2) 693; Yücel (n 2) $239,243$.

38 Öztan (n 2) 693; Hoşlan (n 16) 203, 204. 
alan koşulların gerçekleşmesi ile birlikte evlilik birliğinin temelinden sarsıldığı kabul edilir ${ }^{39}$.

Çalışma konumuz yoksulluk nafakası ise TMK md 175 hükmünde düzenlenmektedir. Aşağıda ayrıntılarına yer verildiği üzere yoksulluk nafakası talep eden tarafın kusuru nafaka yükümlüsünün kusurundan daha ağır olmamalıdır ${ }^{40}$. Bu kapsamda nafaka talep eden tarafın kusurunun nafaka yükümlüsünün kusurundan az olması halinde ya da her iki tarafın da kusuru olmadığı hallerde nafakaya hükmedilebilir. TMK md 175 hükmünden çekişmeli boşanma davalarında yoksulluk nafakası talep edilmişse tarafların kusur durumuna göre karar verileceği ve bu amaçla kusur araştırılması yapılacağı anlaşılmaktadır. TMK md 166/III hükmü kapsamında anlaşma temeline dayalı boşanma davalarında ise tarafların kusur durumu incelenmez. Bununla birlikte TMK md 166/III c 3 düzenlemesi hakimin, taraflarca kabul edilen düzenlemede gerekli değişiklikleri yapabileceğini kabul etmektedir. Boşanmanın mali sonuçlarından olması nedeni ile taraflarca üzerinde anlaşmaya varılması gereken yoksulluk nafakası düzenlemesinde de hakim, tarafların menfaatinin gerektirmesi halinde gerekli değişiklikleri yapabilir. Şu halde hakimin bu incelemeyi yapabilmesi için tarafların kusur durumunu araştırması mı gerekmektedir? Bu soruya olumsuz cevap vermek gerekir. Gerçekten TMK md 166/ III hükmünde yer alan faraziye, evlilik birliğinin temelinden sarsılıp sarsılmadığ ve sarsıldıysa bunda eşlerin kusurlu olup olmadığını araştırmayı engeller. Anlaşma temeline dayalı boşanma davasında taraflar, eşlerden birine yoksulluk nafakası ödeneceği yönünde anlaşmaya varmışsa hakim, nafaka talep eden kişinin daha az kusurlu olup olmadığını inceleyemez. Bu kapsamda TMK md 166/III c 3 düzenlemesinde işaret edilen hakimin müdahalesi kavramının kusur araştırmasını kapsayacağı şeklinde yorumu isabetli olmaz. Bununla birlikte hakimin, tarafların menfaatini göz önünde bulundurarak yoksulluk nafakası düzenlemesine müdahale edebileceğinin kabulü, hakimin bu denetimi yapabilmesi amacı ile araştırma yapmasını gerekli kılmaktadır. Bu kapsamda eşler tarafından dosyaya sunulan bilgi ve belgelere göre gerekirse resen araştırmasını sürdürerek eşler tarafından kabul edilen düzenlemenin hakkaniyetli olup olmadığını incelemelidir ${ }^{41}$.

39 Hakimin, taraflarca kabul edilen düzenlemeyi denetlemesi evlilik birliğinin sarsılıp sarsılmadığına kanaat getirme amacıyla değil anlaşmanın serbest irade ürünü olup olmadığını anlama amacına hizmet etmektedir. Fankhauser (n 12) ZGB Art 111, N 2-3. Karş Jungo (n 11) Art 111 N 1.

40 TMK md 175. Bkz aşa IV, B.

41 Özdemir (n 10) 218; Oktay Özdemir (n 2) 29, 38. ZGB Art 111 hükmünde tarafların bilgi ve belge getirme yükümlülüğü düzenlenmektedir. Getirilmesi gereken belgeler arasında bordro, ücret ve vergi beyannamesi, kira sözleşmesi, sigorta evrakları gibi belgeler yer almaktadır. Bununla birlikte mahkemenin bu belgeleri inceleme görevi sınırlıdır. Mahkeme, taraflarca getirilen evrakların hatalı olduğuna yönelik şüphe verici bir belirti olması halinde bunları inceleyebilir. Bu konuda bkz Fankhauser (n 12) ZGB 111 N 24-25; Jungo (n 11) Art 111 N 13. 


\section{Yoksulluk Nafakasına İlişkin Genel Bilgiler}

\section{A. Yoksulluk Nafakasının Hukuki Niteliği}

TMK md 185/III hükmü ile evlilik birliği esnasında eşlerin birbirine yardımcı olma yükümlülüğü düzenlenmektedir. Bu yükümlülük evlilik birliğinin çözülmesi ile sona ermektedir; ancak kanun koyucu bazı durumlarda eşler arasındaki yardım yükümlülüğünü devam ettirme yolunda tercihini kullanmaktadır ${ }^{42}$. Sosyal yardımlaşma amacı ile kusursuz ya da az kusurlu olan ve boşanma nedeniyle zarurete düşecek olan eşe yardım edilmesinde böyle bir durum mevcuttur ${ }^{43}$.

TMK md 175 hükmünde düzenlenen yoksulluk nafakas1, hukuki niteliği itibari ile kanundan doğan bir yükümlülüktür ${ }^{44}$. Burada kişinin iradesinden bağımsız olarak kaynağını kanundan alan bir yükümlülük söz konusudur ${ }^{45}$. TMK md 166/III hükmünde işaret edilen anlaşmada taraflarca kabul edilen yoksulluk nafakası düzenlemesi de nafaka borcunun sözleşmeye dayandığı yorumunu yapmaya elverişli değildir. Zira burada borcun kaynağı taraflar arasındaki sözleşme değil kanuni koşulların somut durumda bir arada bulunmasıdır ${ }^{46}$. Yine yoksulluk nafakasının tazminat niteliğinde olmadığı hususunda doktrinde görüş birliği mevcuttur ${ }^{47}$. Keza yoksulluk nafakasına hükmedilmesinde nafaka yükümlüsünün kusurunun aranmayacağına ilişkin TMK md 175/II hükmü, nafakanın tazminat niteliğinde olmadığını açıkça göstermektedir. Yoksulluk nafakası ceza niteliğinde de değildir ${ }^{48}$. Aksine evlilik birliğinin sona ermesine bağlı olarak eşler arasındaki yardım yükümlülüğünün sona ermesi neticesinde yoksulluğa düşecek tarafa yardım edilmesi amacını taşımaktadır. Nafaka alacağı ise aile hukukundan kaynaklanan ve kişiye bağlı bir haktır ${ }^{49}$.

42 Azra Arkan Serim, 'Yoksulluk Nafakası' (2007) LXV (1) IÜHFM 277, 285.

43 Öztan (n 2) 833.

44 Mecit Demir, Türk Medeni Hukuk Öğreti ve Uygulamasında Yoksulluk Nafakası (Seçkin Yayıncılık, 2018) 8.

45 Bununla ifade edilen Türk Borçlar Kanununda açıkça düzenlenen borcun kaynaklarına dahil olmayıp bir kanun hükmü nedeniyle borcun doğmuş olmasıdır. Bu konuda bkz Oğuzman ve Öz (n 15) 36; Nomer (n 15) 29.

46 Bühler ve Spühler (n 16) Art 158 N 172; Demir (n 44) 8; Emrah Kulakl1, 'Yoksulluk Nafakası ve Yoksulluk Nafakasının Süresi Bağlamında Bir Mukayeseli Hukuk İncelemesi’ (2018) 5 (2) İstanbul Medipol Üniversitesi Hukuk Fakültesi Dergisi 237, 242. Aksi görüşte Hoşlan (n 16) 203, 247.

47 Öztan (n 2) 833; Ceylan (n 4) 104; Ali Demirbaş, 'Güncel Tartışmalarla Yoksulluk Nafakası' (2018) 5 (2) İstanbul Medipol Üniversitesi Hukuk Fakültesi Dergisi 219, 226; Nafiye Yücedağ, 'Kadının Talep Ettiği Yoksulluk Nafakası' (2017) 6. Uluslararası Suç ve Ceza Film Festivali 509, 510; Abdülkerim Yıldırım 'Yoksulluk Nafakası ve Yoksulluk Nafakasında Süre Sorunu' (2016) 14 (157) 59, 62.

48 Öztan (n 2) 833, Ceylan (n 4) 104; Demirbaş (n 47) 219, 226. Yargıtay Hukuk Genel Kurulu'nun bu yöndeki kararı için bkz 3-1513/1182, 14.11.2019 (Kazancı İçtihat Bankası <www.kazanc1.com.tr> Erişim Tarihi 14 Kasım 2020).

49 Dural, Öğüz ve Gümüş (n 2) 161; Öztan (n 2) 852; Ceylan (n 4) 105; Yücedağ (n 47) 509, 512. Ayrıca bkz Serap Helvac1 Kişilik İşlemi Hakları (Münhasıran Şahsa Bağlı Haklar) (İstanbul Üniversitesi Sosyal Bilimler Enstitüsü, Yayımlanmamış Doktora Tezi, 1993) 22, 39vd. 


\section{B. Yoksulluk Nafakasının Şartlarına Genel Bakış ve Kavramın İnsan Onuru ile İliş̧kisi}

Türk Medeni Kanunumuzda yoksulluk nafakası şu şekilde düzenlenmektedir: "Boşanma yüzünden yoksulluğa düşecek taraf, kusuru daha ağır olmamak koşuluyla geçimi için diğer taraftan malî gücü oranında süresiz olarak nafaka isteyebilir. Nafaka yükümlüsünün kusuru aranmaz."

Türk Medeni Kanunumuzda yoksulluk nafakasına hükmedilebilmesi için gerekli bazı şartların gerçekleşmesi aranmaktadır. Bunlardan ilki nafakanın talep edilmesidir.

TMK md 175/I c 1 hükmünde boşanma yüzünden yoksulluğa düşecek tarafın nafaka isteyebileceği düzenlenerek yoksulluk nafakasının talebe bağlı olduğu hüküm altına alınmaktadır. EMK ${ }^{50}$ md 144 'ten farklı olarak her iki eş de maddede yer alan koşulların gerçekleşmesi ile birlikte yoksulluk nafakası talep edebilir; erkeğin yoksulluk nafakası talep edebilmesi için ilave bir koşul bulunmamaktadır ${ }^{51}$. Yoksulluk nafakasının talebe bağlı oluşu, taraflarca TMK md 166/III kapsamında kabul edilen düzenlemede nafaka hususunda sessiz kalınması ve nafakadan feragat edilmiş olması hallerinde önem taşır. Bu hususlara aşağıda ayrıca yer verilmektedir ${ }^{52}$.

TMK md 175/I ve II hükmü uyarınca yoksulluk nafakasına hükmedilebilmesinin ikinci koşulu, nafaka talep eden kişinin kusurunun nafaka yükümlüsünün kusurundan ağır olmaması ya da her iki tarafın kusursuz olmasıdır. Buna ilaveten eşlerin kusurunun eşit olması halinde de nafakaya hükmedilmesi gerektiği doktrinde ileri sürülmektedir ${ }^{53}$.

Yoksulluk nafakasına hükmedilebilmesi için Türk Medeni Kanununda aranan bir diğer şart, yoksulluk nafakası talep eden kişinin boşanma nedeni ile yoksulluğa düşecek olmasıdır ${ }^{54}$. TMK md 175 hükmünde yer alan bu ifadeden yoksulluğun boşanma nedeni ile oluşması, yoksulluk ile boşanma arasında uygun illiyet bağının mevcut olması gerektiği anlaşılmaktadır ${ }^{55}$.

Doktrinde boşanma sonrasında çalışma imkanından mahrum olması ve mevcut malvarlığı ile geçimini sağlayamayacak durumda olması nedeniyle kendi geçimini sağlayamayacak duruma düşen tarafin, diğer taraftan yoksulluk nafakası talep

s0 Türk Kanunu Medenisi, Kanun Numarası: 743, Kabul Tarihi: 4.4.1926, RG: 4.4.1926/339.

51 EMK md 144/I: "Boşanma yüzünden yoksulluğa düşecek eş, kusuru daha ağır olmamak şartıyla geçimi için diğer eşten mali gücü oranında süresiz olarak nafaka isteyebilir. Ancak, erkeğin kadından yoksulluk nafakası isteyebilmesi için, kadının hali refahta bulunmast gerekir.”

52 Bkz aşa $\mathrm{V}, 1$ ve 4

53 Öztan (n 2) 838; Kürşad Yağcı 'Yoksulluk Nafakasında Süresizlik Sorunu' (2018) 76 (1) İstanbul Hukuk Mecmuası 323, 324; Kulaklı (n 46) 237, 245.

54 Madde metninde boşanma yüzünden yoksulluğa düşecek taraf ifadesi yer almakla beraber TMK md 158/II hükmü gereği evliliğin butlan ile sona ermiș olması halinde de yoksulluk nafakasına hükmedilebilir. Bu yönde bkz Yağcı (n 53) 323, 324; Arkan (n 42) 277, 286; Yildırım (n 47) 59, 64.

55 Öztan (n 2) 842. 
edebileceği belirtilmektedir ${ }^{56}$. Bununla birlikte yoksulluğa düşme ifadesinin nafaka talep eden kişinin hiçbir işte çalışmıyor olması gerektiği şeklinde yorumlanmaması gerekliliği de haklı olarak ifade edilmektedir ${ }^{57}$. Yargitay kararları incelendiğinde de yoksulluğun yeme, giyinme, barınma, sağlık, ulaşım, kültür (eğitim) gibi bireyin maddi varlığını geliştirmek için zorunlu ve gerekli görülen harcamaları karşılayacak düzeyde geliri olmayanlar şeklinde tanımlandığ 1 görülmektedir ${ }^{58}$. Bununla birlikte nafaka talep eden tarafin asgari ücrete sahip olması yoksulluk nafakası bağlanmasını olanaksız kılan bir olgu olarak kabul edilmemektedir ${ }^{59}$. Türk Medeni Kanununda yoksulluk kavramı tanımlanmadığından maddede yer alan kural içi boşluk nedeniyle hakim, somut uyuşmazlı̆̆ın özellikleri, ülkenin ekonomik ve sosyal yapısına göre takdir yetkisini kullanarak yoksulluk şartının gerçekleşip gerçekleşmediği yönünde karar vermelidir ${ }^{60}$.

Belirtmemiz gerekir ki yoksulluk nafakasının miktarının belirlenmesinde nafaka yükümlüsü tarafın mali gücü dikkate alınmalıdır ${ }^{61}$. Nafaka yükümlüsünün mali gücü yeterli değilse yoksulluk nafakasına hükmedilmemelidir ${ }^{62}$. Buna karşılık nafaka yükümlüsünün mali gücünün çok iyi olması diğer tarafa verilecek nafakanın aynı oranda yüksek olması sonucunu doğurmaz ${ }^{63}$. Nafaka yükümlüsü ne kadar varlıklı olursa olsun esas olan nafaka talep eden kişinin boşanma nedeniyle düştügü yoksulluğun, zaruret halinin giderilmesidir. Bu kapsamda hakim tarafindan belirlenecek yoksulluk nafakasının, nafaka talep eden tarafın zorunlu geçim masraflarını ve onu yoksulluktan kurtaracak miktarı geçmemesi esastır ${ }^{64}$. Zira yoksulluk nafakasının amacı, evlilik birliğinin devamı sırasındaki hayat standartlarının devam etmesi değil boşanma nedeni ile yoksulluğa düşecek tarafa verilecek katkı ile onun yeni hayat şartlarına uyum sağlamasını desteklemektir ${ }^{65}$.

56 Mustafa Şahin 'Türk-İsviçre Medeni Kanunlarına Göre Evlilik Sonrası Katkının (Yoksulluk Nafakasının) Şartları (TMK m.175-ZGB m.125)' (2017) XXI (3) Gazi Üniversitesi Hukuk Fakültesi Dergisi 75, 81; Arkan (n 42) 277, 289-290.

57 Şahin (n 56) 75, 81. Ayrıca bkz Uzun (n 2) 37-43.

58 Yargitay Hukuk Genel Kurulu 2-656-688, 7.10.1998; Yargitay 3 HD, 16747/174, 18.1.2016; Yargitay 3 HD, 9825/13574, 7.9.2015 (Kazancı İçtihat Bankası <www.kazancı.com.tr> Erişim Tarihi 2 Ocak 2021).

59 Yargıtay 3 HD, 9290/15148, 19.11.2014 (Kazancı İçtihat Bankası <www.kazancı.com.tr> Erişim Tarihi 12 Ocak 2021).

60 Öztan (n 2) 835; Arkan (n 42) 277, 289.

${ }_{61}$ Ingeborg Schwenzer ve Andrea Büchler, Dritte Abschnitt: Die Scheidungsfolgen/ Art. 125/I.-II., FamKomm (3. Bask1, Stämpfli Verlag, 2017) Art 125 N 1; Dieter Freiburghaus, Personen-und Familienrecht- Partnerschaftsgesetz Art.1-456 ZGB, Handkommentar zum Schweizer Privatrecht (3. Bask1, Schultess Juristische Medien AG, 2016) Art 125, N 22; Dural, Öğüz ve Gümüş (n 2) 157; Uzun (n 2) 70vd; Demirbaş (n 47) 219, 225; Kulaklı (n 46) 237, 249; Demir (n 44) 48.

${ }_{62}$ Schwenzer ve Büchler (n 61) Art 125 N 3; Demir (n 44) 48; Şahin (n 56) 75, 87; Gediz Kocabaş, 'Evlilik Sonrası Dayanışma İlkesi ve Bu İlkenin Sınırı Olarak Clean Break İlkesi Doğrultusunda Yoksulluk Nafakasını Belirleyici Ölçütler' (2013) 19 (1) 357, 371; Yildırım (n 47) 59, 69.

63 Dural, Öğüz ve Gümüș (n 2) 157; Şahin (n 56) 75, 87.

64 Ömer Uğur Gençcan, 6100 sayıl HMK Hükümlerine Göre Boșanma, Tazminat ve Nafaka Hukuku (2. Bask1, Yetkin, 2013) 1002, Haluk Burcuoğlu, ‘Boşanmada Kusur ve Yoksulluk Nafakası ile İlgili Gözlemler' (2018) 4 (2) İstanbul Aydın Üniversitesi Hukuk Fakültesi Dergisi 1, 6. Taraflarca kabul edilen düzenlemede nafaka talep eden lehine tazminat ödenmesi yönünde anlaşmaya varılmışsa ya da edinilen malların paylaşılması neticesinde kişinin yoksulluk durumunun önüne geçilmișse boșanma davasından sonra açtığı nafaka istemli davanın reddi mümkündür (Burcuoğlu (n 64) 1, 9-10; Arkan (n 42) 277, 290; Kulaklı (n 46) 237, 243. Ayrıca bkz Uzun (n 2) 49-57). Mal rejiminin tasfiyesi TMK md 166/III hükmünde ifade edilen düzenlemenin zorunlu unsuru değildir; ancak tarafların mal rejiminin tasfiyesine ilişkin anlaşması mümkündür.

65 Şahin (n 56) 75, 87; Arkan (n 42) 277, 293. Karş Öztan (n 2) 839. 
$\mathrm{Bu}$ nedenle nafaka talebinde bulunan tarafın zaruri geçim ihtiyaçlarından fazla nafakaya hükmedilmesi gerekmediği belirtilmektedir ${ }^{66}$.

Burada, çoğunlukla mali gücü çok yüksek kişilerin oldukça yüksek miktarlarda yoksulluk nafakası ödemesi yönünde verilen kararlar veya tasdik edilen protokoller neticesinde yoksulluk nafakası kavramının ve sınırlarının bulanıklaştığını ifade etmek gerekmektedir. Yoksulluk nafakası kavramını medyanın sunuş şekli ile ele aldığımızda kavramın, düzenleniş amacına ters düşen iki farklı yüzü ile karşılaşmaktayız. Bunlardan ilki, nafaka talep eden kişinin yoksulluğa düşmesi şartının göz ardı edildiğidir. İkincisi ise nafaka talep eden tarafın zaruret halinin önüne geçilmesi amacından sapılarak nafaka yükümlüsünün mali gücü ne kadar iyiyse o oranda nafakaya hükmedileceğidir. Bunun neticesinde evlilik birliğinin bir kere kurulmuş olması ile (özellikle) kadınların bir ömür boyu "rahat edeceği" ifade edilerek yoksulluk nafakasına yönelik köklü değişikliklerin yapılması gerektiği ifade edilmektedir. Halbuki Türk Medeni Kanunumuzda düzenlenen yoksulluk nafakasında amaç, evlilik birliği sona ermesine rağmen boşanma nedeniyle yoksulluğa düşecek tarafa yardım yükümlülüğünün belirli koşullar altında devamıdır. TMK md 175 hükmü ile, boşanma yüzünden yoksulluğa düşecek tarafın geçimi için diğer taraftan süresiz olarak nafaka isteyebileceği düzenlenerek yoksulluğa boşanma yüzünden düşülecek olması koşulu açıkça aranmaktadır ${ }^{67}$. Eşlerden birinin yoksulluğuna kendi tembelliği, dolandırılması ya da iflası neden olmuşsa yoksulluk ile boşanma arasında illiyet bağının bulunmadığından nafaka isteminin reddi gerekir ${ }^{68}$. Bununla birlikte eşlerden birinin yoksulluğa düşecek olması onun hayati, zorunlu giderlerini karşılayamayacak olmasını işaret etmektedir ${ }^{69}$. Yoksa eşin evlilik birliğinin devam ettiği sürece sahip olduğu hayat standardına nazaran daha düşük bir mali güce sahip olması onun yoksulluğa düştüğü anlamını taşımamaktadır ${ }^{70}$. Nitekim TMK md 175 ve mehaz ZGB Art 125 hükümlerinde yer alan yoksulluk nafakasının hukuki dayanağı evlilik değil evlilik sonrası dayanışmadır ${ }^{71}$.

Esasen TMK md 176/III hükmünde yer alan ve nafaka alacaklısının yoksulluğunun ortadan kalkması halinde nafakanın mahkeme kararıyla kaldırılacağını düzenleyen hüküm, nafakanın yoksulluk devam ettiği müddetçe söz konusu olacağını ifade etmektedir. Şu halde TMK md 175 hükmünde düzenlenen yoksulluk nafakası ile

66 Arkan (n 42) 277, 293; Kulaklı (n 46) 237, 249.

67 Kanun koyucunun amacının yoksulluğa düşecek olan eşin diğer eş tarafından şartları bulunduğu sürece ekonomik yönden desteklenmesi ve asgari yaşam gereksinimlerinin karşılanması olduğu yönünde bkz Anayasa Mahkemesi, 2011/136, 17.5.2012. RG Tarih ve Sayı: 26.6.2012, 28335.

68 Öztan (n 2) 843; Arkan (n 42) 277, 290; Kulaklı (n 46) 237, 248. Eşin kendi kusuru nedeni ile yoksulluğa düşmüs olması halinde evlilik sonrası katkı talebinin kısmen ya da tamamen reddedilebileceği ZGB Art 125/III'te özel olarak düzenlenmektedir.

69 Arkan (n 42) 277, 290; Eray Aksın Atar, 'Nafakadan Feragat' (2016) 22 (3) MÜHFHAD Cevdet Yavuz'a Armağan 251, 258.

70 Arkan (n 42) 277, 290; Yücedağ (n 47) 509, 512. Karş Öztan (n 2) 839.

71 Schwenzer ve Büchler (n 61) Art 125 N 4. 
boşanma nedeniyle yoksulluğa düşen tarafın yoksulluğu ortadan kalkıncaya dek insan onuruna yaraşır şekilde yaşaması amaçlanmaktadır ${ }^{72}$.

Bu konuda İsviçre Medeni Kanunu ve Alman Medeni Kanununun yoksulluk nafakası düzenlemelerine yer vermek uygun olacaktır.

Türk Medeni Kanunu md 175 hükmüne kaynaklık eden ZGB Art 125 hükmünde Evlilik sonrası katkı ${ }^{73}$ başlığı ile Türk Medeni Kanununda yerini bulan yoksulluk nafakası düzenlenmektedir.

ZGB Art $125^{74}$ ile eşlerden birinin kendi bakımını uygun koşullarda sağlamasının haklı olarak beklenemediği durumlarda diğer eşin hakkaniyete uygun katkıda bulunmakla yükümlü olduğu düzenlenmektedir. Hakimin, bir eşe evlilik sonrası katkıda bulunulması ve bunun miktarı ile süresi yönünde karar verebilmesi için özellikle şu kriterlerij ${ }^{75}$ göz önünde bulundurması gerekmektedir:

1. Evlilik birliği süresince eşlerin görev dağılımı

2. Evlilik birliğinin devam ettiği süre ${ }^{76}$

3. Evlilik sırasındaki hayat standardi ${ }^{77}$

4. Eşlerin yaşı ve sağlığ 1

5. Eşlerin gelir ve malvarlığ

6. Eşler tarafindan sağlanacak olan çocuğa ilişkin bakım yükümlülüğünün kapsamı ve süresi

72 TMK md 175 hükmünün insan onurunu koruyan bir düzenleme olduğu yönünde: Öztan (n 2) 833

73 Türk hukukunda nafaka yerine evlilik sonrası katkı teriminin kullanılmasının isabetli olacağı yönünde: Yağcı (n 53) 323, 324.

74 İsviçre'de 1998'de kabul edilen ve 1.1.2000 tarihinde yürürlüğe giren Kanunla boşanma hukuku alanında köklü bir revizyon yapılmıştır. Bu revizyon öncesinde yoksulluk nafakası kurumu ZGB Art 152 ve 153 'te düzenlenmekteydi.

75 ZGB Art 125/II,1-8. ZGB Art 125 hükmünde yer alan kriterlerin revizyon öncesi İsviçre hukuk uygulamasında yerleşmiş kriterler olduğu yönünde Schwenzer ve Büchler (n 61) Art 125 N 1. Benzer kriterlere PEFL 2:4 hükmünde de yer verilmektedir. Bu kriterler ve açıklamaları için bkz Cristina Gonzalez Beilfuss, 'CEFL's Maintenance Principles: The Conditions For Maintenance' (2005) Common Core and Better Law in European Family Law 83, 91-95.

76 İsviçre hukuk uygulamasında evlilik ne kadar uzun sürerse evlilik birliği içerisindeki görev dağılımının o kadar yerleşik hale geleceği (örneğin bir eşin sürekli ev işleri ile ilgilenmekle yükümlü olacağı) ve kişinin kendine yetme durumunun zayıflayacağı belirtilmektedir. Bu kapsamda nafakanın miktarı ve süresinin belirlenmesinde evlilik süresinin önemli bir kriter olduğu ifade edilmektedir. Uygulamada beş yıla kadar olan evlilikler kısa süreli, on yıldan fazla süren evlilikler ise uzun süreli evlilik olarak kabul edilmekte, beş ve on yıl arasında süren evliliklerde ise somut durumun göz önünde tutulacağı belirtilmektedir. Ivo Schwander, OFK-Orell Füssli Kommentar (Gözden Geçirilmiş 3. Bask1, Orell Füssli Verlag AG, 2016) N 8 .

77 Bu bent uyarınca boşanma sonrasında evlilik birliği içerisindeki hayat standardını korumaya yetecek miktarda nafakaya hükmedilmesi gerektiği düșünülebilirse de bu kriter madde metninde yer alan tüm kriterlerle birlikte değerlendirilmeye alınmaktadır. Çok uzun süren evliliklerde bu kriterin belirleyici olduğu görüşü mevcuttur. Zira bu tür uzun süreli evliliklerde evlilik süresince sahip olunan hayat standardının devam edeceğine yönelik haklı güvenin korunması gerektiği belirtilmektedir. Bununla birlikte eşlerin boşanma davasından önce uzun zamandır ayrı yaşıyor olmaları halinde (örneğin 10 yıl, BGE 130 III 537, 17.6.2004) zaten ortak bir hayat standardından bahsedilemeyeceği için bu kriterin etkisi silikleșir. Bu yönde Schwenzer ve Büchler (n 61) Art 125 N 5-6. Evlilik sırasındaki hayat standardının evlilik sonrası katkının üst limiti olduğu yönünde: Freiburghaus (n 61) Art 125 N 6. Yazar; ancak tarafların bir yatırım yapma amacı ile birikim yapıyor oluşu nedeniyle gereken standardın altında yaşam sürmesi gibi istisnai hallerde katkı miktarının hayat standardının üstüne çıkabileceğini belirtmektedir (Freiburghaus (n 61) Art 125 N 8). 
7. Eşlerin mesleki eğitimi ve istihdam olasılıkları ile iş hayatına yeniden dahil olması için gerekli muhtemel harcamalar

8. Yaşlılık aylığı, hayat sigortası ödemeleri, mesleki ya da özel veya resmi yardım sandığı ile birlikte bunların çıkış ödeneklerinin muhtemel paylaşımları dahil olmak üzere beklenen muhtemel gelirler

Bununla birlikte tarafların; aileye karşı yükümlülüklerini ağır biçimde ihmal etmesi, kendi kusuru neticesinde muhtaç duruma düşmüş olması ve katkı sağlayacak tarafa ya

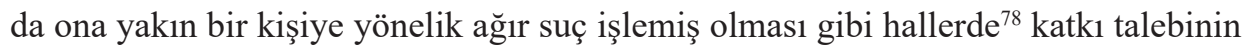
kısmen ya da tamamen reddedilebileceği ZGB Art 125/III’te düzenlenmektedir.

Belirtmemiz gerekir ki, İsviçre Medeni Kanununda ZGB Art 122-125 hükümleri ile boşanmanın sonuçları arasında mesleki emeklilik konusu düzenlenmektedir ${ }^{79}$. ZGB Art 125 hükmü ise eşin diğer eşe evlilik sonrası yapacağı katkıyı düzenlemektedir. Katkı ödemekle yükümlü kılınan tarafın borcunu ifa etmemesi halinde kantonların belirlediği yetkili kurumun katkı alacaklısına kural olarak karşılıksız yardımda bulunacağı ise ayrıca düzenlenmektedir ${ }^{80}$. Bu düzenlemeler ile boşanma nedeniyle katkı talep edebilecek kişinin zaruret halinin esasen sosyal devlet anlayışı ile çözümlenmeye çalışıldığı ve ancak bu şekilde çözüme kavuşulamaması halinde ve şartları mevcutsa boşanılan eşin katkı yükümlüsü olduğu, bununla birlikte katkı borcunun ifa edilmemesi halinde yetkili kurumun yardım edeceği anlaşılmaktadır ${ }^{81}$.

Alman Medeni Kanununda ise Kişisel Sorumluluk İlkesi başlıklı BGB §1569 hükmü ile tarafların boşanmadan sonra kendi geçimlerini sağlamakla yükümlü olduğu açıkça düzenlenmektedir ${ }^{82}$. Bu kapsamda evlilik birliği içerisindeki dayanışma ilkesinin boşanma ile birlikte güçsüzleşerek yerini kişisel sorumluluğa bıraktığını ve ancak BGB $§ 1570$ ve devam eden maddelerde yer alan istisnai hallerde evlilik sonrası nafaka ödenmesine karar verileceği anlaşılmaktadır ${ }^{83}$. İstisnai olarak belirtilen bu haller arasında yaşlılık (BGB §1571), hastalık veya düşkünlük (BGB

78 ZGB Art 125/III’te belirtilen sebepler sınırlı sayıda sayılmamıştır. Örnekler için bkz Freiburghaus (n 61) Art 125 N 48.

79 Şahin (n 56) 75, 83.

80 ZGB Art 131.

81 Şahin (n 56) 75, 83.

82 Eşlerin evlilik birliğinin sona ermesinden sonra kendi geçimlerini sağlamakla yükümlü olduğu kişisel sorumluluk ilkesi clean break ilkesi olarak adlandırılmaktadır. Bu ilke ile evlilik birliği sona erdikten sonra taraflar arasındaki ekonomik ilişkiye en kısa süre içinde son verilmesi amaçlanmaktadır. Bu kavram hakkında ayrıntılı bilgi için bkz Kocabaş (n 62) 357, 364-368; Demirbaş (n 47) 219, 222; Şahin (n 56) 75, 91; Beilfuss (n 75) 83, 87. Clean break ilkesi; ancak kişinin kendi geçimini sağlamasının haklı olarak beklenemeyeceği durumlarda ve diğer eşin mali gücünün yeterli olması halinde hakkaniyete uygun bir katkı1 mümkün kılar (Freiburghaus (n 61) Art 125 N 3). Ne var ki günümüzde evlilik süresince evin düzeni ve çocuğun bakımı daha ziyade kadının sorumluluğundadır. Kadınların, evlilikle birlikte dezavantajlı konumunu sürdürdükçe kadına olan katkının devam etmesi gerektiği ileri sürülmekte, clean break ilkesinin daha ziyade kendi mali gücüne sahip ve çoğunlukla çocuksuz eşler açısından anlaşılır olduğu ifade edilmektedir. Bu konuda bkz Geoffrey Shannon 'Clean Break or Long-Term Payment of Maintenance' (2005) Common Core and Better Law in European Family Law 103, 105 .

83 BGB §1569. PEFL 2(2) hükmünde, nafaka talebinin koşullarının oluştuğu durumlar haricinde her eşin boşanmadan sonra kendi geçimini sağlamakla yükümlü olduğu düzenlenmektedir. 
§1571) ortak çocuğun bakımının gerektirmesi (BGB §1570) gibi hakkaniyetin nafaka ödenmesini gerektiren haller sayılmaktadır.

Yukarıda aktarıldığı üzere BGB sistematiğinde, bir eşe diğeri tarafından evlilik sonrası katkıda bulunulmasının gerçekten "zaruri hallere” hasredildiği görülmektedir. Belirtmek gerekir ki, İsviçre Medeni Kanununda, Alman Medeni Kanununun aksine tarafların boşanmadan sonra kişisel sorumlu olduğuna yönelik açık bir hüküm bulunmamaktadır ${ }^{84}$. Bununla birlikte ZGB Art 122-125 arasında yer alan hükümler ile ZGB Art 125 hükmünde 8 bent halinde sayılan kriterlerin dikkate alınması gerekliliği bu hukuk sisteminde de evlilik sonrası katkının çerçevesini çizmektedir. Bu çerçevede nafaka (katkı) alacaklısının gerçekten ihtiyaç içinde olan eş olduğu belirtilmelidir. Esasen Türk Medeni Kanunumuzda düzenlenen yoksulluk nafakası kavramı da benzer bir ihtiyacı işaret etmektedir. Gerçekten TMK md 175 hükmünde düzenlenen nafakanın; ancak boşanma yüzünden (boşanma ile uygun illiyet bağ1 içerisinde) yoksulluğa düşecek kişi tarafından ve geçiminin sağlanması amacı ile sınırlı olarak istenebileceği koşulu ZGB Art 125 ve BGB §1569 düzenlemelerine paralel bir anlayışı göstermektedir. Pek tabii ideal olan, İsviçre hukukunda olduğu gibi boşanma nedeniyle güç duruma düşen kişinin zaruret halinin sosyal devlet imkanları ile giderilmesidir. Devlet imkanları ile halen daha gerekli koruma sağlanamaması halinde ZGB Art 125 hükmünde yer alan kriterler dikkate alınarak boşanılan eşin nafaka yükümlüsü olarak kabulü en uygun olandır ${ }^{85}$. Ne var ki pozitif hukukumuzda böyle bir düzenlemenin bulunmaması ve boşanılan eşin "süresiz"86 olarak nafaka ödemekle yükümlü kılınması TMK md 175 hükmünün insan onuru kavramı ile yakın ilişkisini göz ardı etmeyi haklı k1lmaz. TMK md 175 hükmündeki düzenleme ile boşanma yüzünden yoksulluğa düşen tarafın yoksulluğunun giderilmesi amaçlanmakta, kişinin insan onuruna yaraşır şekilde ve elverişli koşullarda yaşaması arzulanmaktadır.

\section{Hakimin}

\section{Yoksulluk Nafakasına Müdahalesinin Sınırları}

Anlaşma temeline dayalı boşanma davalarında taraflarca kabul edilen düzenlemeye hakimin müdahalesi konusu beraberinde şu soruyu getirmektedir: Taraflarca kabul

84 ZGB Art 125 hükmünde evlilik birliği sonrası dayanışma ilkesi ve clean break ilkesinin bir arada oluğu yönünde Schwander (n 76) ZGB 125 N 1. Ayrica bkz Freiburghaus (n 61) Art 125 N 1.

85 Doktrinde Devletin, evlilik birliğinin sona ermesine bağlı mağduriyetleri giderme hususunda iki tür katkısı olabileceği ifade edilmektedir. Nafakanın ödenmesini adi bir borç olarak görmeyerek ödenmesini sağlayacak tedbirlere yer verilmesi ve nafaka ödenmediğinde nafaka yükümlüsüne rücu etmek kaydı ile Devlet tarafından ödeme yapılması böyledir. Bu kapsamda TMK md 198 hükmünde düzenlenen ve evlilik birliğini koruyan tedbirin nafaka hususunda tanınması düşünülebileceği ifade edilmektedir. Diğer bir tedbir ise nafaka borcunun ödenmesini tehlikeye düşüren hallerde nafaka yükümlüsünden teminat istenmesidir. Bununla birlikte Devletin nafaka alacaklısını koruma amaçlı alacağı en etkili tedbir sonradan nafaka yükümlüsüne rücu etmek kaydı ile ödenmemesi halinde nafaka borcunun Devlet tarafından ödenmesidir; ancak bu konuda verilen kanun telifi kabul edilmemiştir. Bu konuda ayrıntılı bilgi için bkz Oktay Özdemir (n 2) 29, 43-45; Demirbaş (n 47) 219, 232.

${ }^{86}$ Bu konudaki görüşlerimiz için bkz aşa $\mathrm{V}, 5$. 
edilen düzenlemeye müdahale edilebilir mi yoksa tarafların arzuları her zaman üstün mü tutulmalıdır? Bunu takip eden sorun ise müdahaleye cevaz verilen hukuk sistemlerinde müdahalenin sınırını belirlemekte yatmaktadır.

Belirtmek gerekir ki hakimin müdahalesi konusunda neredeyse tüm hukuk sistemlerinde ikili bir ayrım yapılmakta ve çocuğun durumu ile mali sonuçlar ayrı ayrı değerlendirmeye alınmaktadır. Çoğu hukuk sisteminde hakim, çocuğun durumuna ilişkin düzenlemelere müdahale etme hususunda tam yetkilidir ${ }^{87}$. Sadece çocuğa ilişkin düzenlemenin geçerli olup olmadığı değil içeriğinin de çocuğun yararını gözetip gözetmediği incelenmektedir. $\mathrm{Bu}$ bağlamda çocuğun durumuna ilişkin düzenlemenin mahkemeye yöneltilen bir öneri niteliğinde olduğu belirtilmektedir ${ }^{88}$. Konumuz yoksulluk nafakası ve boşanmanın diğer mali sonuçlarına müdahale hususunda ise daha liberal bir yaklaşım olduğu belirtilmelidir. Mali sonuçlara yönelik düzenlemelere müdahaleyi dışlayan hukuk sistemlerini bir kenara bıraktığımızda hakimin müdahalesinde genel olarak iki farklı yöntem olduğu görülmektedir: Hakime tam müdahale yetkisinin verilmediği ve düzenlemenin geçerli olup olmadığı gibi sözleşmesel incelemeye müsaade eden yöntem ve bunun karşısında hakimi, tarafların menfaatini göz önünde tutarak düzenlemenin hakkaniyetli olup olmadığ 1 da dahil olmak üzere denetlemekle yükümlü kılan diğer yöntemden söz edilmesi mümkündür ${ }^{89}$.

Avrupa Birliği Aile Hukuku Prensiplerini incelediğimizde de hakimin müdahalesinin kapsamının çocuklar ve mali sonuçlara ilişkin farklı olduğu görülmektedir. Çocuğun durumuna ilişkin düzenlemenin geçerli olup olmadığına ilaveten çocuğun menfaatlerine uygun olup olmadığı konusunda da hakime denetim ödevi verilmektedir ${ }^{90}$. Buna karşılık mali sonuçlara ilişkin anlaşmaların ise geçersizlik yönünden denetleneceği düzenlenerek hakimin müdahalesi sinırlı tutulmaktadır ${ }^{91}$. Bununla birlikte geçersizlik kavramının içerik ve yorumu iç hukuka bırakılmakta ve hatta iç hukukta (geçersizlik denetimine ilaveten) hakkaniyet denetimi gibi daha kapsamlı bir denetim getirilebilmesinin mümkün olduğu ifade edilmektedir ${ }^{92}$. Avrupa Birliği Aile Hukuku alanını uyumlaştırarak en uygun prensipleri oluşturan PEFL düzenlemesi bağlayıcı değildir; ancak olması gereken hukuk açısından boşanmanın mali sonuçlarına müdahalenin sınırlı tutulması yönündeki tutumu önemlidir.

87 Frederique Ferrand, 'Divorce and Spousal Agreements' (2005) Common Core and Better Law in European Family Law 71, 78 ; Roth (n 3) 51 .

$88 \quad$ Ferrand (n 87) 71, 78. Bkz BGB § 1697 a.

89 Mali sonuçlara yönelik düzenlemelerde hakimin müdahalesini dışlayan hukuk sistemlerinden biri İsveç hukuk sistemidir (Ibid 71, 78).

90 Roth (n 3) 51. PEFL 1:7 (1)'de eşlerin yaptıkları anlaşmanın; ancak çocuğun yararına olduğu sonucuna varılırsa onaylanacağı düzenlenmektedir.

91 PEFL 1:7(2).

92 Ferrand (n 87) 71, 79. Hakimin mali sonuçlara yönelik müdahale yetkisinin geniş tutulması halinde eşler arasında çok fazla uyuşmazlıkla karşılaşılmasının mümkün olacağı ve bunun anlaşmalı boşanma davalarını olumsuz etkileyeceği yönünde: Roth (n 3) 51 . 
İsviçre hukukunda ZGB Art 111/II hükmünde hakimin boşanma ve boşanmanın sonuçları hususundaki anlaşmanın serbest ve dikkatlice düşünülmüş bir iradenin ürünü olduğuna ve çocuklara ilişkin düzenlemenin onaylanabilir olduğuna kanaat getirmesi halinde boşanma kararı vereceğini düzenlemektedir. Doktrinde de hakimin taraflar arasındaki düzenlemeyi denetlemesinin iki işlevi bulunduğu belirtilmektedir: Anlaşmanın, tarafların serbest ve olgun iradesinin ürünü olup olmadığına kanaat getirmek ve anlaşmanın uygulanabilir olup olmadığına karar vermek ${ }^{93}$. Anlaşmanın uygulanabilir olup olmadığı hususunda anlaşmanın tamamlanmış olması, hükümlerin açık olması ve hakkaniyete açıkça aykırı bir düzenleme barındırmıyor olması belirleyicidir $^{94}$.

TMK md 166/III hükmünde ise hakimin, taraflarca kabul edilen düzenlemede tarafların ve çocukların menfaatini göz önünde bulundurarak gerekli değişiklikleri yapabileceği ifadesi ile hakimin kabul edilen düzenlemeye müdahalesinin kapsamı geniş tutulmaktadır. Gerçekten TMK md 175 hükmünde tarafların üzerinde serbestçe tasarrufta bulunamayacağı ve hakimin takdirine tabi olan çocuğun durumuna ilişkin konular ile tarafların serbest tasarrufuna tabi mali sonuçların denetimi hususunda ayrıma gidilmemiştir. Bununla birlikte hakimin, boşanmanın mali sonuçlarına yönelik denetim ödevinin ve takdir yetkisinin geniş yorumlanmaması yerinde olur. Gerçekten hakimin müdahale hususunda takdir yetkisinin varlı̆̆ı, hakimin kendini tarafların yerine koyarak ve kendi takdirine göre sözleşme içeriğini belirlemesi anlamına gelmemektedir ${ }^{95}$. Hakimin müdahalesi, taraflarca kabul edilen düzenlemeyi uygun görmemesi halinde taraf menfaatlerine uygun düşen öneriyi ortaya koymakla sinırlıdır ${ }^{96}$. Bu kapsamda hakim düzenlemeyi neden uygun görmediğini ve değişiklik önerisinin gerekçelerini taraflara açıklamalıdır ${ }^{97}$.

\section{Tarafların Yoksulluk Nafakası Hususunda Sessiz Kalması}

TMK md 166/III hükmünde belirtilen "taraflarca kabul edilen düzenlemede" tarafların yoksulluk nafakasına ilişkin hiçbir beyanının olmaması ya da tutanağa geçirilen sözlü anlaşmalarının yoksulluk nafakasına ilişkin bir düzenleme içermemesi ele alınması gereken ilk problemdir. Bu halde hakim yoksulluk nafakası hakkında; ancak talep edilmesi halinde karar verebileceği gerekçesiyle nafaka hususunda sessiz kalınan anlaşmayı uygun görebilir mi? Bu soruya olumsuz yanıt vermek gerekir. Zira

"Bu konuya ait anlașma mahkemece uygun bulunmuyorsa hakimin görevi taraflardan gerekli gördüğ̈̈ değișiklikleri yapmalarını istemek ancak onların kabulü halinde boşanmaya karar vermekten ibarettir. Mahkemenin kendisini tarafların yerine koyarak ve kendi takdirine göre maddi ve manevi tazminat ile yoksulluk nafakasına hükmetmesi mümkün olmayacağından manevi tazminat isteğinin reddi gerekirken yazll şekilde hüküm kurulması usul ve kanuna aykırıdır." Yargitay 2 HD, 10499/14491, 21.11.1991 (Lexpera <lexpera.com.tr> Erişim Tarihi 10 Eylül 2020).

96 Özdemir (n 10) 211.

$97 \quad$ Ibid 211. 
TMK md 166/III hükmü tarafların, boşanmanın mali sonuçları hususunda anlaşmış olmasını aramaktadır. Boşanmanın mali sonuçlarından olan yoksulluk nafakası hususunda anlaşmaya varılması da anlaşma temeline dayanan boşanma davalarında maddi şart haline getirilmiştir ${ }^{98}$. Bu nedenle yoksulluk nafakasına ilişkin düzenleme barındırmayan sözlü veya yazılı anlaşmanın hakim tarafından uygun görülmeyerek onaylanmaması gerekmektedir. Hakimin taraflara yoksulluk nafakası hususunda bir anlaşmaya varılması yönünde müdahalesi taraflarca kabul edilir ve taraflar yoksulluk nafakası yönünden anlaşmaya varırsa TMK md 166/III c 4 uyarınca boşanmaya hükmolunur. Tarafların hakim tarafından önerilen değişikliği kabul etmemesi halinde boşanmanın mali sonuçları yönünden anlaşmaya varılmadığı kabul edilir ki bu durumda anlaşma temeline dayalı açılan boşanma davasının reddi gerekmektedir ${ }^{99}$. Bununla birlikte Yargıtay'ın tutumu tarafların anlaşamaması halinde anlaşmalı boşanma davasının çekişmeli davaya dönmesi ve taraflara delil ibrazı için süre verilmesi şeklindedir ${ }^{100}$.

$\mathrm{Bu}$ başlık altında üzerinde durulması gereken diğer ihtimal, yoksulluk nafakası hususunda sessiz kalınmasına rağmen hakimin ihmali neticesinde uygun görülerek kesinleşen boşanma kararından sonra yoksulluk nafakasının talep edilip edilemeyeceğidir.

$\mathrm{Bu}$ konuda doktrinde ileri sürülen bir görüşe göre anlaşma temeline dayalı boşanma davaları kesinleşen tarafların, boşanmanın mali sonuçları hususunda da anlaştığı kabul edilir ve kesinleşmeden sonra yoksulluk nafakası isteminin reddi gerekmektedir ${ }^{101}$.

Doktrinde ileri sürülen bizim de katıldığımız diğer görüş ise hakimin ihmaline bağlı olarak kesinleşen boşanma davalarından sonra tarafların yoksulluk nafakası

98 Özdemir (n 10) 186; Öztan (n 2) 695.

99 Bu yönde bkz Dural, Öğüz ve Gümüş (n 2) 125; Elçin Grassinger (n 2) 235, 237; Yücel (n 2) 239, 241.

100 "Açılanan nedenlerle mahkemece, tarafların boşanmanın mali sonuçlart ve çocukların durumu hakkında düzenlemelere ilişkin olarak tarafların beyanlarının alınması, bu beyanların özgür iradeleri ile açıklandı̆̆ı sonucuna varılırsa ve düzenleme uygun bulunur ise bu doğrultuda boşanma kararl verilmesi; düzenlemenin uygun bulunmaması hâlinde ise anlaşmada gerekli görülen değişikliğin yapılarak, değişiklik yapılan hususlarda madde hükmünün öngördüğü şekilde taraflara bir öneride bulunulması, öneri kabul edildiği taktirde buna göre karar verilmesi, kabul edilmediği ve taraflarca anlaşmaya varllarak mahkemenin de uygun bulacağ l yeni bir düzenleme de yapılmadiğı taktirde, davanın Türk Medeni Kanununun 166/1. maddesi uyarınca çekişmeli boşanma olarak sürdürülüp sonucu uyarınca karar verilmesi gerekir.' Yargıtay Hukuk Genel Kurul Kararı, 2-2643/484, 18.4.2019. Benzer yönde kararlar için bkz Yargıtay 2 HD, 3974/4370, 5.10.2020, Yargıtay 2 HD 4548/7998, 3.7.2019, Yargitay 8 HD, 9159/9855, 5.11.2019 (Kazancı İçtihat Bankası <www. kazancı.com.tr> Erişim Tarihi 24 Aralık 2020).

101 Özlem Kırbaş, Türk Hukuku'nda Eşlerin Anlaşmasına Dayanan Boşanma: (MK.m.134/III), (İstanbul Üniversitesi Sosyal Bilimler Enstitüsü, Yayımlanmamış Yüksek Lisans Tezi, 1994) 70. TMK md 166/III kapsamındaki protokoller açısından aynı yönde: Hoşlan (n 16) 203, 240. Yazar, TMK md 184/V hükmü kapsamında olan ve anlaşmalı boşanmanın aksine sulh amacı gütmeyen ve belirli bir zorunlu içeriği olmayan protokoller açısından ise sonradan dava açılabileceğini belirtmektedir (Ibid 203, 240). 
talep edebileceği yönündedir ${ }^{102}$.

Yargıtay Hukuk Genel Kurulu'nun kararına konu bir olayda da taraflar boşanmanın diğer mali sonuçlarından olan maddi ve manevi tazminat hususunda sessiz kalmış, dava kesinleştikten sonra tazminat davası açılmıştır. Kurul, anlaşma temeline dayalı boşanma davalarında kusur araştırması yapılmadığı, sonradan açılan davada kusur araştırması yapılarak tazminat hakkında karar verilmesinin bozmayı gerektirdiği yönünde karar vermiştir. Kanaatimizce bu karar iki noktada hatalıdır: İlki, hakimin denetim ödevini yerine getirerek anlaşmaya müdahale etmiş olması gerekmesine rağmen ihmali neticesinde kesinleşen boşanma kararından sonra tarafların dava açamayacağının kabulünün hukuka aykırı oluşudur. İkincisi ise boşanmadan sonra açılan davada kusur araştırması yapılarak tazminat yönünde karar verilmesinde bir isabetsizlik olmamasıdır. Nitekim TMK md 166/III hükmünde yer alan faraziyenin kusur araştırmasını engellediği doğru olmakla beraber bu faraziye daha sonra açılacak davada kusur araştırması yapılmasını engeller nitelikte değildir.

\section{Yoksulluk Nafakasına Yönelik Anlaşmanın Gelecek Yıllara İlişkin Düzenleme İçermemesi}

$\mathrm{Bu}$ ihtimalde taraflarca kabul edilen düzenleme yoksulluk nafakasına ilişkin anlaşmayı içermektedir. Ne var ki taraflar nafakanın sonraki yıllarda değişim oranı hususunda sessiz kalmaktadır. Hakimin değişen şartlara uyarlanmasını sağlayacak bir artış oranı hususunda tarafların anlaşmasını araması aksi halde anlaşmayı uygun görmeyerek müdahale etmesi gerekli midir?

Hemen belirtmek gerekir ki, yoksulluk nafakası gibi yoksulluk nafakasının gelecek yıllarda ne miktarda ödeneceğinin karara bağlanması da talebe bağlıdır ${ }^{103}$. Bununla birlikte taraflar nafakanın sonraki yıllardaki değişim oranına ilişkin bir düzenleme hususunda anlaşmaya varmışsa hakim bu düzenlemeyi TMK md 166/ III c 3 uyarınca denetlemekle yükümlüdür. Zira burada esasen ihtiyari olan; ancak taraflarca görüşmelere taşınması nedeniyle sübjektif esaslı unsur haline gelen artış oranı üzerinde hakimin denetleme ödevi mevcuttur. Bu kapsamda hakkaniyete aykırı olması nedeni ile tarafların menfaatine uygun düşmediği kanaatine ulaştığı anlaşmaları uygun görmeyerek değişiklik yapılması yönünde öneride bulunması gerekmektedir. Yargitay Hukuk Genel Kurul kararına konu bir olayda da ifade edildiği üzere bir

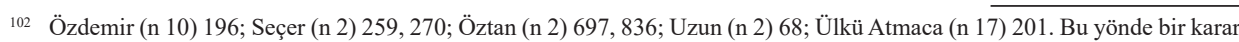
şöyledir: "Somut olayda, her ne kadar, davacı taraf, boşanma davası dava dilekçesinde, yoksulluk nafakası talep etmemiş ise de, doğmamış bulunan bir haktan feragat mümkün olmadığından, koşulları oluştuğu takdirde, davacının karşı taraftan yoksulluk nafakası talep etmesi mümkündür. Öyle ise mahkemece, bu ilke ve esaslar gözetilerek, davacının boşanma davası sırasında, açıkça yoksulluk nafakasından feragat ettiğini de belirtmemiş olması karşısında, tarafların ekonomik ve sosyal durumlarl ve hakkaniyet esaslarl gözetilerek, uygun bir nafakaya hükmedilmesi gerekirken, yanilgll değerlendirme sonucu yazılı şekilde hüküm tesisi bozmayı gerektirmiştir." Yargitay 3 HD, 23009/1638, 5.02.2013 (Lexpera <lexpera.com.tr> Erişim Tarihi 17 Ocak 2020).

103 TMK md176/V hükmünde hakimin istem üzerine irat biçiminde ödenmesine karar verilen nafakanın gelecek yıllarda ne miktarda ödeneceğini karara bağlayabileceği düzenlenmektedir. 
tarafın zenginleşmesine diğer tarafınsa fakirleşmesine neden olan artış oranının değiştirilmesi yönünde müdahalede bulunulması asıldır ${ }^{104}$. Taraflar arasında kabul edilen düzenlemede nafakanın sonraki yıllarda değişmeyeceği kabul edilmişse bu defa bu kaydın TMK md 23 hükmüne aykırı olup olmadığ incelenmelidir ${ }^{105}$. Bununla birlikte taraflarca yoksulluk nafakasının sonraki yıllara yönelik değişimi hususunda sessiz kalınmışsa bu durum TMK md 166/III hükmünde yer alan zorunlu unsurlar arasında sayılmadığından hakimin müdahale etme yükümlülüğü bulunmadığ kanaatindeyiz ${ }^{106}$.

\section{Yoksulluk Nafakası Düzenlemesinin Saklı Tutulması}

Taraflar TMK md 166/III hükmü kapsamında açılan davada evlilik birliğinin sona ermesi ve çocukların durumuna ilişkin bir anlaşmaya varmış olup boşanmanın mali sonuçlarına ilişkin çözümü sonraya bırakabilir mi? Bu halde taraflar, çocuğun velayeti, iştirak nafakası ve velayetin bırakılmadığı eş ile kişisel ilişki kurulması gibi çocuğun durumunu ilgilendiren konularda anlaşmaya varmaktadır. Taraflar bu anlaşmanın uygun görülerek boşanmaya karar verilmesini arzularken yoksulluk nafakası veya tazminatı saklı tutarak bu hususların çözümünü boşanmadan sonraya bırakmayı amaçlamaktadır.

Kanaatimizce bu durumda anlaşma temeline dayalı boşanma davasının maddi şartının yerine gelmediğinden söz etmek gereklidir ${ }^{107}$. TMK md 166/III hükmü doğrultusunda serbest iradeleri ile evlilik birliğinin sona ermesi hususunda anlaşmaya varan tarafların maddede belirtilen zorunlu unsurlar hususunda da anlaşmaya varması aranmaktadır. Gerçekten tarafların ancak boşanma ve boşanmanın sonuçları hususunda anlaşmaya varmış olmaları halinde TMK md 166/III hükmünde yer alan özel usulden faydalanmaları mümkündür. Nafaka yönünden anlaşmaya varamayan eşlerin TMK md 166/III hükmünde düzenlenen özel usulden faydalanması yerinde değildir ${ }^{108}$. $\mathrm{Bu}$ kapsamda maddede yer alan zorunlu unsurlar hususunda anlaşmaya varamayıp bunun çözümünü sonraya bırakmaları halinde esasen taraflarca boşanmanın mali

104 "Nafaka, nafaka yükümlüsünü cezalandırıcı bir nitelik taşımamalıdır. Taraflar arasında düzenlenen boşanma protokolünde kararlaştırılan iştirak nafakasının her yıl \%20 oranında artırlmasina ilişkin hüküm; bir tarafin zenginleşmesine, diğer tarafin ise fakirleşmesine yol açacak niteliktedir. "Hâkim; insana, tabiata, gerçeğe, olağana sirt çevirmeden ve katı kalıplar içinde sıkışıp kalmadan uyuşmazlı̆̆a insan kokusu taşıyan bir çözüm getirmek zorunluluğundadır" ( Yargıtay 1.H.D. 31.12.1976 tarih ve 1976/9370 E-13138 K. sayll ilamı ). Bu sebeple, dava tarihinden sonraki dönemler için ylllık artış oranının ÜFE-TEFE'ye göre belirlenmesi, 4721 Sayll TMK'nın 4. maddesi gereğince hakkaniyete daha uygundur." Yargıtay Hukuk Genel Kurul Kararı, 3-1513/1182, 14.11.2019 (Kazancı İçtihat Bankası <www.kazancı.com.tr> Erişim Tarihi 2 Ocak 2021). Karar iştirak nafakası yönünden verilmişse de hakimin çocukların durumuna ilaveten boşanmanın mali sonuçlarını da denetleme ödevi bulunduğundan yoksulluk nafakası yönünden de aynı sonuca ulaşılması mümkündür.

105 Öztan (n 2) 851.

106 Aksi görüş için bkz Hoşlan (n 16) 203, 250. Yazar, sonraki yıllara ilişkin artış içermeyen düzenlemenin onaylanmasının eksik incelemeye dayandığını belirtmekte, ÜFE oranında artışın sözleșmenin örtülü içeriğinde yer aldığının kabul edilmesi ve talepte bulunulmasına gerek olmaksızın bu artışın yıllık olarak kendiliğinden gerçekleşmesine izin verilmesi gerektiğini belirtmektedir (Ibid 203, 250).

107 Aynı yönde Seçer (n 2) 259, 268.

108 Bu tür uygulamaların Kanunun ruhu ve sistematiğine aykırı olacağı yönünde: Gençcan (n 64) 709. 
sonuçları hususunda varılan bir anlaşmadan söz etmek uygun olmaz. Burada tarafların yoksulluk nafakasının miktarı hakkında anlaşmaya varmamış olması ile nafakaya ilişkin sorunun çözümünün sonraya bırakılması arasında fark yoktur. Bu nedenle hakimin, yoksulluk nafakası talebinin saklı tutulduğu düzenlemeyi uygun bulmayarak tarafların nafaka hususunda anlaşmaya varmasını araması gerekmektedir. Yargıtay'ın da tarafların tazminat haklarını saklı tutması halinde TMK md 166/III hükmünde işaret edilen boşanmanın mali sonuçları hususunda anlaşmaya varılamadığı ve ihtilafın devam ettiğinden bahisle anlaşmalı boşanma kararı verilemeyeceği yönünde kararı mevcuttur ${ }^{109}$. Karşı oy yazısından çıkarımda bulunabildiğimiz bir başka kararında ise boşanmanın mali sonuçlarını saklı tutan düzenlemenin uygun görülerek tasdik edilmiş olmasını bozma sebebi yapmadığı anlaşılmaktadır ${ }^{110}$.

Peki taraflar, yoksulluk nafakası hususundaki çözümü, karar vermesi amacı ile hakime bırakabilir mi? Diğer bir ifade ile boşanma konusunda serbest iradeleri ile anlaşmaya varan tarafların çocukların durumu ya da boşanmanın mali sonuçlarına ilişkin hususların çözümünü mahkemeye bırakması mümkün müdür?

Belirtmek gerekir ki yukarıdaki soruya İsviçre Medeni Kanununda yanıt verilmektedir. ZGB Art 112 hükmü ile tarafların ortak bir başvuru ile mahkemeden boşanma kararı verilmesini ve anlaşma sağlayamadıkları hususlarda mahkemenin karar vermesini isteyebileceği ifade edilmektedir. Kısmi anlaşmalı boşanmayı düzenleyen bu madde Türk Medeni Kanunumuza alınmamıştır. Durum böyleyken kısmi anlaşmalı boşanmanın Türk hukukunda da uygulanabilir bir kurum olduğu kanaatindeyiz. Zira bu ihtimalde taraflar boşanma yönünde anlaşmaya varmış; ancak boşanmanın mali sonucuna ilişkin çözümü hakime bırakmıştır. Hakimin çözümünün taraflarca kabul edilmesi halinde artık taraflarca kabul edilen bir anlaşma söz konusu olur. Aksi ihtimalde ise tarafların mali sonuçlar hususunda anlaşmaya varamadığ 1 anlaşılır ki bu durumda TMK md 166/III uyarınca açllan davanın reddi gerekir. Esasen taraflarca davanın başında boşanmanın mali sonuçları hususunda anlaşmaya varılmış; ancak uygun görülmeyerek yeni bir çözüm getirilmiş olması ihtimalinde de tarafların, hakim tarafından getirilen çözüm doğrultusunda bir anlaşmaya varması söz

109 "Tarafların irade beyanları esas alınarak boşanmalarına karar verilebilmesi için, diğer şartların yanında boşanmanın mali sonuçları ile çocukların durumu hususunda tam olarak anlaşmış olmaları, hakimin de taraflarca kabul edilen düzenlemeyi uygun bulması şarttır. Tazminat haklarının saklı tutulması, bu husustaki ihtilafin devam ettiğini ve bu ihtilafin çözümünün ileriye bırakıldı̆̆ını gösterir. Başka bir ifade ile "tazminat haklart saklı tutulmak" suretiyle anlaşmalı boşanma kararl verilemez. Bu husus nazara alınmadan "tazminat haklartnın sakl tutulması" suretiyle Türk Medeni Kanununun 166/3 maddesi gereğince boşanma kararı verilmesi doğru bulunmamıștır. Taraflar boșanmanın mali sonuçları üzerinde anlaşamadıklarına göre, gösterdikleri deliller toplanarak davanın Türk Medeni Kanununun 166/1-2 maddesi çerçevesinde değerlendirilip, hasl olacak neticesine göre karar verilmesi gerekirken, bu yön nazara alınmadan hüküm tesisi usul ve yasaya aykırı olup, bozmayl gerektirmiştir. "Yargıtay 2 HD, 16344/269, 13.1.2015 (Kazancı İçtihat Bankası <www.kazanc1. com.tr> Erişim Tarihi 25 Kasım 2020).

110 Karşı oy yazısının ilgili kısmı şöyledir: "Taraflar, aralarında düzenledikleri ve hakime sundukları 6.9.2007 tarihli protokolde "birbirlerindeki maddi ve manevi tazminat hakların sakl tuttuklarını" belirtmişlerdir. Hakkın sakl tutulması, bu konuda anlaşma sağlanmadı̆̆ını, çekişmenin devam ettiğini ihtilafin ileriye atıldı̆̆ını gösterir. Boşanmanın mali sonuçlarından olan maddi ve manevi tazminatla ilgili çekişme giderilmeden Türk Medeni Kanununun 166/3. maddesi gereğince boşanmaya hükmedilemez." Yargıtay 2 HD,19916/959, 28.1.2009 (Lexpera <lexpera.com.tr> Erişim Tarihi 23 Aralik 2020). 
konusudur. Bu ihtimal ile tarafların nafakaya yönelik çözümü mahkemeye bırakması benzerdir. Bu kapsamda TMK md 166/III hükmünün kısmi anlaşma temeline dayalı boşanma davalarını dışlamadığı kanaatindeyiz ${ }^{111}$.

\section{Yoksulluk Nafakasından Feragat Edilmesi Meselesi}

TMK md 166/III hükmünde ifade edilen taraflarca kabul edilen düzenlemede tarafların yoksulluk nafakasından feragat etmesi mümkündür.

Doktrinde TMK md 166/III hükmü uyarınca açılan davada yoksulluk nafakasından feragat edilmiş olması halinde usulüne uygun beyanın mevcut olduğu hallerde yoksulluk nafakasından feragatin geçerli olduğu belirtilmektedir ${ }^{112}$. Buna ilaveten geçerli bir feragatin söz konusu olduğu hallerde tarafların daha sonra nafaka talep edemeyeceği yönünde görüş birliği bulunmaktadır ${ }^{113}$.

Yargıtay'ın bazı kararlarında feragat iradesinin açık olması gerekliliği aranmaktayken bazı kararlarında örtülü yapılan feragatin de geçerli olacağına karar verilmektedir. Gerçekten Yargıtay Hukuk Genel Kurul kararına konu bir olayda anlaşma temeline dayalı boşanma davasında açıkça yoksulluk nafakasından feragat edildiğine yönelik beyanda bulunulmasa da anlaşmalı boşanmanın kesinleşmesi ile istenebilecek tek nafakanın iştirak nafakası olduğu ifade edilmektedir ${ }^{114}$. Bununla birlikte son yıllarda geçerli bir feragatten söz edilebilmesi için yoksulluk nafakası isteminden açıkça vazgeçildiği yönünde bir dilekçe veya tutanağa aktarılmış usulüne uygun açık bir feragat beyanının aranması gerektiği yönünde isabetli kararlarının mevcut olduğu görülmektedir ${ }^{115}$. Yine, Yargıtay'ın nafaka isteminden feragat eden tarafın daha sonra nafaka talep edemeyeceği yönünde katı ve istikrarlı tutumu mevcuttur.

Belirtmemiz gerekir ki, hakimin müdahalesinin kapsamı, feragat iradesinin açık olup olmadığını denetlemekle sınırlı tutulmamalıdır. Burada esas sorun bazı durumlarda TMK md 23/I hükmü kapsamında geçersiz bir feragatin bulunması ihtimalidir. Şöyle ki; yoksulluk nafakasının insan onurunu korumayı amaçlayan yapısı göz önünde bulundurulduğunda bu düzenlemeyi içeren sözleşmelerin TMK

\footnotetext{
Aynı yönde Özdemir (n 10) 224. Aksi görüşte Hoşlan (n 16) 203, 214.

$112 \operatorname{Atar}(\mathrm{n} 69) 251,258$.

113 Öztan (n 2) 837; Atar (n 69) 251, 259; Yücel (n 2) 239, 249; Demir (n 44) 71.

114 “Hukuk Genel Kurulu'nun çoğunluğunca, tarafların boşanma sırasında nihai olarak anlaştıklarını bildirdikleri ve nafaka isteğinden feragat edildiği, davacının bu beyanında açıçca yoksulluk nafakasından sözedilmemiş ise de kendisini bağlayacağı, anlaşmalı boşanmanın kesinleşmesi ile istenebilecek tek nafakanın çocuklar için iştirak nafakası olduğu, somut olayda, davacının boşanma yüzünden yoksulluğa düştüğ̈̈nden bahisle nafaka isteyemeyeceği, yerel mahkeme kararının usul ve yasaya uygun olduğu benimsenmiş ve bu nedenle direnme kararının onanması gerekmiştir." Yargıtay Hukuk Genel Kurul Kararı, 836/306, 6.3.2013 (Lexpera <lexpera.com.tr> Erişim Tarihi 12 Ocak 2021).

115 Yargıtay 3 HD, 14455/18101, 21.11.2011. Benzer yönde kararlar için bkz Yargıtay 3 HD, 1018/1738, 15.2.2016; Yargıtay 3 HD, 5574/13801, 21.10.2014; Yargıtay 3 HD, 18910/301, 19.1.2016 (Lexpera <lexpera.com.tr> Erişim Tarihi 15 Ocak 2021).
} 
md 23 hükmü denetimine tabi olması gerekliliği ortaya çıkmaktadır ${ }^{116}$. Boşanma nedeniyle yoksulluğa düşecek olan ve kendi geçimini sağlamasının haklı olarak beklenemeyeceği tarafin nafakadan feragat etmesi halinde bu feragatin geçerli olup olmadığı ayrıca irdelenmelidir. Özellikle diğer eşin mali gücünün yerinde olmasına rağmen boşanmaya karar verilebilmesi amacı ile nafakadan feragat eden; ancak boşanma yüzünden hayatını idame ettiremeyerek zarurete düşmüş olan eşin feragati TMK md 23/I'e aykırılık nedeni ile geçersiz olabilir. Bu konuda irade sakatlı̆̆ boyutuna varmayan durumlarda TMK md 23 hükmünün işlevi belirgindir. Hatta hakimin onaylamasından sonra irade sakatlı̆̆ının oldukça istisnai hallerde iptale neden olacağ $1^{117}$ göz önünde bulundurulduğunda, feragatin geçerli olup olmadığ1 hususunda TMK md 23 hükmünün denetimsel işlevi ayrıca belirleyici olacaktır.

$\mathrm{Bu}$ bağlamda kanaatimiz nafakadan feragat edilmesi halinde hakimin, bu feragatin TMK md 23 hükmüne aykırı olup olmadığını incelemesi gerektiğidir. Taraflarca getirilen veya hakim tarafindan resen incelemeye alınan bilgi ve belgeler neticesinde bir tarafin açıkça sömürülmesine neden olan veya onu insana yaraşır bir yaşam sürdürmekten mahrum kılan düzenlemenin tespit edilmesi halinde hakimin müdahalesi söz konusu olmalıdır. Öte yandan TMK 23 hükmüne aykırı olması nedeni ile kesin hükümsüz olan bir sözleşmenin hakim tarafından uygun görülmüş olması halinde dahi sözleşmenin geçersizliğini koruduğu belirtilmelidir. Bu nedenle Yargitay'in katı tutumunun aksine ${ }^{118}$ daha evvel nafakadan feragat eden kişinin nafaka istemli dava açması halinde hakimin irade sakatlığının mevcut olup olmadığına ilaveten feragatin TMK md 23 hükmü karşısında geçerli olup olmadığını da incelemesi gerekmektedir. Bu inceleme bağlamında sözleşme özgürlüğüne aykırı bir durumun mevcut olup olmadığının takdirinde sözleşmenin yapıldığı tarih nazara

116 TMK md 23/1 hükmünün koruduğu değerler arasında kişinin özgür ve insan onuruna yakışır bir yaşam sürmesi amac1 yer almaktadır. Bkz Oktay Özdemir (n 30) 337, 401.

117 Esasen hakimin onayından sonra tarafların irade sakatlığı nedeniyle düzenlemeyi nasıl iptal edeceği de tartışılmaya müsaittir. Gerçekten hakimin tarafları bizzat dinleyerek iradelerini serbestçe açıkladıklarına kanaat getirmesini öngören TMK md166/III hükmü, hakimin taraf iradelerinin irade sakatlığına uğramış olup olmadığını incelemesine hizmet eder. Hakimin tarafları bizzat dinleyerek irade sakatlığının mevcut olup olmadığı değerlendirmesinde bulunması nedeniyle daha sonradan tarafların irade sakatlığına başvurmasının mümkün olmadığı belirtilmektedir ( Özer (n 16) 323). Bununla birlikte yanılma durumunda taraflar dahi iradelerinin sakat olduğunu bilmediğinden hakimin de bu yönde değerlendirmede bulunamayacağı gerekçesi ile yanılma durumunda taraflara iptal hakkı tanınması gerektiği görüşü ileri sürülmektedir (Bkz Özer (n 16) 323. Karș Esener 610, 622). Daha evvel ifade ettiğimiz üzere hakimin onay șartı, sözleșmenin özel hukuk sözleşmesi niteliğini değiştirmez (bkz yuk II). Ne var ki hakimin uygun görerek tasdik ettiği ve hükmün bir parçası haline gelen düzenlemenin tek taraflı irade beyanıyla iptali mümkün değildir. Aksi düşünüldüğünde taraflardan birinin tek taraflı irade beyanıyla iptal hakkını kullandığını tespit edecek ilk derece mahkemesi ile bizatihi protokolü tasdik eden diğer ilk derece mahkemesi kararları arasında çelişki olur. Bu nedenle eşlerden birinin hataya düşmüş olması halinde bunun ancak istinaf veya temyiz sebebi olușturabileceği belirtilmektedir. Bununla birlikte aynı zamanda sulh sözleșmesi karakteri taşıyan bu düzenlemelerde temel hatası durumunda iptalin sınırlanması gerektiği ifade edilmektedir. Zira taraflar bu düzenleme ile belirli bir riski üzerlerine alarak uyuşmazlığı çözüme erdirmek niyetindedir. Bu kapsamda taraflar arasındaki düzenleme ile çözüme kavuşturulmuş olan belirsiz veya tartışmalı noktalara ilişkin tarafların riski üzerine aldığı ve yanılma hükümlerine başvurmalarının mümkün olmadığ kabul edilmektedir. İstisnai olarak anlaşma yapılırken temel alınan ve kesin olarak kabul edilen bir hususta yanılmaya düşülmüşse iptalin mümkün olduğu belirtilmektedir ( $\mathrm{Bu}$ görüşler ve konu hakkında ayrıntılı bilgi için bkz Özer (n 16) 326-330).

118 "Irade bozukluğu hallerinde, feragatin iptali istenebilir (HMK m. 311). Bunun haricinde feragat beyanından dönülemez. Hal böyle iken davalı-davacı kadının 15.04.2014 tarihli dilekçe ile talep ettiği yoksulluk nafakası talebinin feragat nedeniyle reddine karar verilmesi gerekirken yazılı şekilde kadın lehine yoksulluk nafakasına hükmedilmesi doğru görülmemiş ve bozmayl gerektirmiştir" Yargıtay 2 HD, 23479/4466, 18.4.2017 (Lexpera <lexpera.com.tr> Erişim Tarihi 21 Aralık 2020). 
alınarak karar verilmelidir. Bu yönde yapılan incelemede nafaka talep eden tarafın önceki feragatinin geçersiz olduğu sonucuna varılırsa ve şartları mevcutsa taraf lehine nafakaya hükmedilmelidir. Bununla birlikte nafakadan feragati geçersiz olan kişinin sonradan mali gücünde iyileşme olması halinde bu durum sözleşmeyi baştan itibaren geçerli hale getirmez. Ne var ki bu yeni davada nafakaya ilişkin yoksulluk şartının eksikliği nedeniyle istemin reddi gerekir.

\section{Yoksulluk Nafakasının Belirli Bir Süreye İlişkin Verileceği Yönünde Düzenleme Yapılması}

Taraflarca kabul edilen düzenlemede nafaka yükümlüsünün belirli bir süre için nafaka ödeyeceğinin kararlaştırılması halinde bu düzenleme hakim tarafından uygun görülerek onaylanabilir mi? Bu hususta TMK md 175 hükmünde yer alan “...diğer taraftan süresiz olarak nafaka isteyebilir” ifadesinin belirli süre için nafaka verilmesine cevaz verip vermediği tartışılmalıdır.

Belirli süre ile sınırlı olmak koşulu ile nafakaya hükmedilmesi, çoğunlukla çekişmeli boşanma davalarında nafakanın belirli bir süre için irat halinde ödenmesine karar verilmesi durumunda ihtilafa yol açar. Zira bu gibi hallerde nafaka talep eden taraf TMK md 175 hükmü uyarınca lehine süresiz nafakaya hükmedilmesini talep ederken nafaka yükümlüsü taraf nafakaya hükmedilmemesi ya da belirli süre için hükmedilmesi yönünde talepte bulunmaktadır. Bu kapsamda taraflar arasında nafakanın ödenme süresine ilişkin bir anlaşma bulunmadığı açıktır. Halbuki anlaşma temeline dayalı boşanma davalarında taraflar nafakanın belirli süre için ödenmesi hususunda anlaşmaya varmış olabilir. Bununla birlikte tarafların bu yöndeki anlaşmasını hakimin uygun görüp görmeyeceği tartışılmalıdır. Zira TMK md 175 hükmünde yer alan düzenleme belirli süreli nafaka verilmesini dışlamaktaysa tarafların kanunen düzenlenmiş bu hususa aykırı olarak anlaşma yapması mümkün olmadığından hakim tarafından bu düzenlemenin uygun görülmemesi gerekmektedir ${ }^{119}$. Bu nedenle hakimin belirli bir süre için nafaka verilmesi yönünde takdir yetkisi olup olmadığını incelemek gerekmektedir.

Belirtmemiz gerekir ki İsviçre Medeni Kanununda ve Alman Medeni Kanununda nafakanın (katkının) süresiz istenebileceğine yönelik bir düzenleme mevcut değildir. İsviçre hukukunda yoksulluk nafakasına karar verilecekse nafakanın miktarı ve süresi hususunda ZGB Art 125 hükmünde 8 bent halinde yer alan kriterler özellikle dikkate alınır. Bu kapsamda maddede yer alan kriterler göz önünde tutularak belirli bir süre için nafaka verilmesi yönünde karar verilmesi mümkündür ${ }^{120}$. Alman hukukunda da BGB $§ 1570$ ve devam eden hükümlerde yer alan istisnai koşulların varlığı halinde yoksulluk nafakasına hükmedilmektedir. Bununla birlikte her iki hukuk sisteminde de nafakanın süresi için öngörülmüş bir azami süre bulunmamaktadır.

119 Elçin Grassinger (n 2) 235, 236.

120 Schwander (n 76) ZGB 125 N 5-6; Freiburghaus (n 61) Art 125 N 2. 
TMK md 175 hükmünde ise yoksulluğa düşecek taraf (...) diğer taraftan mali gücü oranında süresiz olarak nafaka isteyebilir ifadesi mevcuttur. Bununla birlikte bu ifadenin belirli süre için nafaka verilmesi yönünde hakime takdir yetkisi verip vermediği konusunda görüş birliği bulunmamaktadır ${ }^{121}$.

TMK md 175 düzenlemesinde yer alan “...süresiz olarak...” ifadesinin Anayasa’ya aykırılığ 1 iddiası Aile Mahkemesi sifatıyla Kestel Asliye Hukuk Mahkemesi tarafından itiraz yolu ile Anayasa Mahkemesi önüne getirilmiştir. Başvuruda, TMK md 175 hükmünde nafakanın hangi hallerde verileceğinin açık olmadığı, nafakanın miktar ve süresinin tayininde evliliğin süresi, tarafların mali gücü gibi unsurların dikkate alınması gerekliliğinin yer almadığı ve bu hali ile boşanma neticesinde eşlerden birinin ömür boyu sürecek mali yükümlülük altına girdiği belirtilmiştir. Anayasa Mahkemesi kararında ise, süresiz ibaresinin kişinin ölünceye kadar her zaman yoksulluk nafakası alacağı anlamına gelmediği ifade edilerek "süresiz olarak" ibaresine yer verilmesinin amacı, boşanmadan dolayı yoksulluğa düşecek olan eşin diğer eş tarafından, şartları bulunduğu sürece ekonomik yönden desteklenmesi ve asgari yaşam gereksinimlerinin karşılanması olduğu belirtilmiştir ${ }^{122}$. Oy çokluğu ile alınan kararda madde metninde yer alan süresiz ifadesinin Anayasa'ya aykırı olması nedeni ile iptali isteminin reddine karar verilmiştir ${ }^{123}$.

Anaysa Mahkemesi, madde metninde yer alan süresiz ifadesinin hukuka aykırı olmadığ1 yönündeki kararına gerekçe olarak bu ifadenin ölünceye kadar nafaka verilmesi anlamına gelmediğine, nafakanın ancak şartları bulunduğu sürece verileceğine yer vermiştir. Pek tabii Türk Medeni Kanununda nafakanın kaldırılması ya da indirilmesine neden olan bir durumun varlığı halinde nafaka yükümlülüğü k1smen ya da tamamen sona $\operatorname{erer}^{124}$. Ne var ki karardan, böyle bir halin mevcut olmadığı ve yoksulluk nafakasının şartlarının devam ettiği durumda nafakanın belirli

121 Nafakanın süresiz olarak ödenmesinin talep edilmesi halinde hakimin süresiz olarak nafakaya hükmetmek zorunda olduğu görüşü için bkz Ahmet Cemal Ruhi, Yargıtay İçtihatlarıyla Nafaka Hukuku (3. Bask1, 2010) 46; Dural, Öğüz ve Gümüş (n 2) 159; Demir (n 44) 71. Nafakanın süresiz olarak talep edilmesi halinde hakimin takdir yetkisi olduğu ve belirli süre ile nafaka ödenmesi yönünde karar verebileceği görüşü için bkz Öztan (n 2) 841; Kocabaş (n 62) 357, 366; Yağc1 (n 53) 323, 340; Yücedağ (n 47) 509, 525. Somut durumda yoksulluğun belli bir süre sonra ortadan kalkacağının açık olduğu hallerde süreli nafakanın mümkün olduğu aksi halde belirli süre ile sınırlandırmanın hakkaniyete aykırı olacağı yönünde Yıldırım (n 47) 59, 78. Nafaka alacaklısının belirli süre nafaka ödenmesini talep etmesi halinde hakimin taleple bağlı olduğu ve belirli süre için nafakaya hükmetmesi gerektiği yönünde Dural, Öğ̈üz ve Gümüş (n 2) 158; Öztan (n 2) 845; Ceylan (n 4) 116; Yıldırım (n 47) 59, 78. Doktrinde ileri sürülen görüşler hakkında ayrıntılı bilgi için bkz Yağcı (n 53) 323, 339-345.

122 Anayasa Mahkemesi, 2011/136, 17.5.2012. RG Tarih ve Say1: 26.6.2012, 28335.

${ }^{123}$ Anayasa Mahkemesi önüne bireysel başvuru yolu ile gelen bir olayda ise aleyhine süresiz olarak nafakaya hükmedilen ve süresiz nafaka nedeniyle maddi ve manevi varlığını koruma hakkının ihlal edildiğini iddia eden başvurucunun, yargılama süresince nafakanın süresiz oluşuna ilişkin şikayet ya da talepte bulunmadığı ve başvuru yollarını usulüne uygun tüketmediğinden bahisle başvurusunun kabul edilemez olduğuna karar verilmiştir. Anayasa Mahkemesi, Esat İnevi Başvurusu, Başvuru Numarası: 2015/11677, 8.7.2020. RG Tarih ve Say1: 23/9/2020-31253.

124 TMK md 176/III ve IV şöyledir: "Írat biçiminde ödenmesine karar verilen maddi tazminat veya nafaka, alacakl tarafin yeniden evlenmesi ya da taraflardan birinin ölümü hâlinde kendiliğinden kalkar; alacaklı tarafin evlenme olmaksızın fiilen evliymiş gibi yaşaması, yoksulluğunun ortadan kalkması ya da haysiyetsiz hayat sürmesi hâlinde mahkeme kararıyla kaldirllır."

Tarafların malî durumlarının değişmesi veya hakkaniyetin gerektirdiği hâllerde iradın artırılması veya azaltılmasına karar verilebilir." 
süreli olarak verilmesinin mümkün olmadığı, başka bir ifade ile nafaka borçlusunun nafaka ödeme yükümlülügünün ölüm ile sona ereceği anlaşılmaktadır. Ancak bu durumun çoğu zaman adaletli olmayan sonuçlar yaratacağı açıktır.

Belirtmemiz gerekir ki Türk Kanunu Medenisinde 3444 sayılı Kanun ${ }^{125}$ ile yapılan değişiklik neticesinde nafakanın bir yıl süre için talep edilebileceğini öngören düzenleme, nafakanın süresiz olarak verilebileceği yönünde değiştirilmiş ve süresizliğe ilişkin bu düzenleme Türk Medeni Kanununa aynen aktarılmıştır ${ }^{126}$. Kanun koyucunun yaptığı bu değişikliğin bilinçli bir değişiklik olduğunu belirten Yargıtay, bu değişiklik neticesinde belirli bir süre için öngörülen nafaka düzenlemesinin kanuna açık bir aykırılık oluşturduğu görüşündedir ${ }^{127}$. Yukarıda belirttiğimiz Anayasa Mahkemesi kararından da TMK md 176 hükmünde yer alan koşulların oluşmadığı hallerde nafakanın süresiz olması gerektiği dolaylı olarak anlaşılmaktadır. $\mathrm{Bu}$ kapsamda İsviçre ve Alman hukukundan farklı olarak Türk hukuku uygulamasında belirli süre ile sınırlı olarak nafakaya hükmedilmesinin TMK md 175 hükmüne aykırı olacağı benimsenmektedir. Biz bu konuda TMK md 175 hükmünde yer alan ifadenin lafzı ve amacının belirli süre için nafakaya hükmedilmesini dışlamadığı ve bu konuda hakimin takdir yetkisi olduğu görüşüne katılmaktayız ${ }^{128}$. Gerçekten TMK md 175 hükmünde yer alan diğer taraftan malî gücü oranında süresiz olarak nafaka isteyebilir şeklindeki ifade nafaka talep eden kişinin süresiz nafaka isteyebileceğini işaret ederken hakime süresiz nafakaya hükmetmesi yönünde bir ödev yüklememektedir. Diğer bir ifade ile pozitif hukukumuzda nafakanın belirli süre için verilmesi mümkündür ${ }^{129}$. Ancak şartları oluşmuşsa hakim pek tabii nafaka yükümlüsünü süre ile sınırlı olmaksızın nafaka ödemekle yükümlü kılabilir.

Esasen birçok durumda hakimin süresiz nafakaya karar vermesi hakkaniyete aykırılık oluşturabilir. Bununla birlikte, istisnai bazı durumlarda nafakanın belirli süre için ödeneceğine karar verilmesi de adil olmayabilir. $\mathrm{Bu}$ nedenle hakimin nafakayı belirli bir zaman için sınırlayabileceği ve istisnai olarak süresiz nafakaya hükmedilebileceğini öngören PEFL 2:8 düzenlemesinin yerinde olduğu kanaatindeyiz ${ }^{130}$. Bununla birlikte pozitif hukukun da belirli süre ile sınırlı olarak nafakaya karar verilmesine engel bir düzenleme içermediğinden bahisle süreye ilişkin

125743 Sayılı Türk Kanunu Medenisinin Bazı Maddelerinin ve 818 Sayılı Borçlar Kanununun 49 uncu Maddesinin Değiştirilmesine Dair Kanun, Kanun Numaras1: 3444, Kabul Tarihi: 4.5.1988, RG 12.5.1988/19812.

126 Türk Kanunu Medenisinin 144. maddesi 4.5.1988 tarihli 3444 sayılı Kanun ile değiștirilmeden önce yoksulluk nafakasının bir y1l süre için talep edilebileceği düzenlenmekteydi. 3444 sayılı Kanunun 6. maddesi ile yapılan değişiklik neticesinde EMK md 144 hükmü ile nafakanın süresiz olarak talep edilebileceği hüküm altına alınmıştır. Nafakanın süresiz olarak talep edilebilir olduğuna yönelik düzenleme Türk Medeni Kanununa aynen aktarılmıştır.

127 Yargitay 2 HD, 8859/14407, 12.12.2017 (Lexpera <lexpera.com.tr> Erişim Tarihi 12 Ocak 2021).

128 Bu görüş ve ayrıntıları için bkz Yağcı (n 53) 323, 346. Madde metninin lafzi yorum ile değerlendirilmesi halinde 1 yıl süren evlilik ile 50 yıl süren evlilik arasında nafaka yönünden farklılık görünmeyeceği hakkında bkz Şahin (n 56) 75,94.

129 Yağcı (n 53) 323, 346; Yücedağ (n 47) 509, 525.

130 Belirlenen sürenin bitiminde yoksulluk nafakası koşullarının devam etmesi halinde tekrar nafakaya hükmedilebileceği yönünde: Beilfuss (n 75) 83, 99. 
bir kanun değişikliğinin uygun olmayacağını düşünmekteyiz. Zira belirli bir süre nafaka verilmesi ya da nafakanın azami süresine ${ }^{131}$ yönelik düzenleme getirilmesi, istisnai durumlarda nafakanın süresiz olarak verilmesini engeller niteliktedir. Esasen mevcut düzenleme ile belirli süreli nafakaya hükmedilebileceğinin kabulü ve süre tayininde ZGB Art 125 hükmünde yer alan kriterlerin dikkate alınması uygun olur ${ }^{132}$. Nafakanın miktarına ilişkin halihazırda dikkate alınan bu kriterlerin nafakanın süresi için de göz önünde tutulmasının önünde kanuni bir engel bulunmamaktadır.

Yukarıda ifade ettiğimiz üzere TMK md 175 hükmü, nafakanın süresiz olarak verilmesine yönelik emredici bir düzenleme niteliğinde değildir. $\mathrm{Bu}$ sebeple, taraflarca kabul edilen düzenlemede belirli süre için kabul edilen nafaka düzenlemesi hakimin müdahalesinin kapsamı dışında kabul edilmelidir.

\section{Hakimin Yoksulluk Nafakası Miktarına Müdahalesi}

Hakimin, taraflarca kabul edilen nafaka miktarının taraf menfaatlerine aykırı olduğuna kanaat getirmesi halinde müdahalesi mümkündür. Ne var ki burada hakimin denetleme ödevini yerine getirirken tarafların serbest iradesine üstünlük tanıması ve ancak açıkça hakkaniyete aykırı durumlarda müdahale etmesi uygun olur. Nitekim yukarıda da ifade ettiğimiz üzere çocuğun durumuna ilişkin düzenlemelerin aksine mali sonuçlara ilişkin düzenlemelerin denetlenmesinde daha liberal bir anlayış hakimdir $^{133}$. Tarafların sözleşme serbestisinin üstün tutulması gerekliliği, hakimin nafaka miktarı hususunda müdahalesinin kapsamını sınırlamaktadır; bununla birlikte bu ifadeden hakimin mali sonuçlara ilişkin anlaşmayı sadece irade sakatlığının mevcut olup olmadığı yönünden denetleyeceği sonucuna varılmamalıdır. TMK md 175 hükmünde hakime mali sonuçlar bakımından da taraf menfaatlerini gözetme ödevi yüklenmektedir. Bu kapsamda nafaka yükümlüsünün mali gücünün çok yukarısında nafaka ödemesine yönelik anlaşma kayıtlarına ${ }^{134}$ ya da nafaka yükümlüsünün mali gücü yerinde olmakla birlikte nafaka alacaklısını yoksulluktan kurtarmayacak kadar düşük oranda belirlenen yoksulluk nafakası kayıtlarına müdahalesi hakkaniyete

\footnotetext{
131 Kanun değişikliği ile nafakanın süresine yönelik bir azami süre getirilmesi gerektiği yönünde: Ruhi (n 121) 46; Yıldırım (n 47) 59, 83; Kulaklı (n 46) 237, 263. Boşandığı eşinden azami süreye kadar nafaka alan kişin yoksulluğunun devam ettiği durumlarda mali desteğin sosyal devlet anlayışı gereği Devlet tarafından karşılanması gerektiği yönünde: Kulaklı (n 46) 237, 263.

132 Yağc1 (n 53) 323, 348.

133 Bkz yuk V.

134 Çok yüksek nafaka verilmesi gibi nafaka yükümlüsünün ekonomik olarak mahvına neden olabilecek kayıtlar yükümlünün kişilik hakkına aykırılık teşkil edebilir. Çok yüksek tazminat verilmesi yönünde aynı sonuca varan görüş için bkz Hoşlan (n 16) 203, 237.
} 
uygun olacaktır ${ }^{135}$. Burada da esas olan hakimin sözleşmenin neden taraf menfaatine aykırı olduğunu açıklayarak sözleşme önerisini sunmasıdır. Yoksa hakim, kendi kanaatine göre uygun olan nafaka miktarı yönünde anlaşılması hususunda tarafları zorlayamaz $^{136}$.

\section{Sonuç}

Türk Medeni Kanunumuzun 166/III fikrası ile uygulamada anlaşmalı boşanma olarak adlandırılan boşanma sebebi düzenlenmektedir. Bu hüküm kapsamında eşlerin boşanmasına karar verilebilmesi için taraflarca kabul edilecek bir düzenlemenin mevcudiyeti gerekmektedir. Bununla birlikte taraflarca kabul edilen düzenleme eşler hakkında boşanma kararı verilmesi için yeterli değildir. Bu düzenlemenin hakim tarafindan uygun bulunması gerekmektedir.

TMK md 166/III hükmünde hakimin, tarafların ve çocukların menfaatini gözeterek taraflarca kabul edilen düzenlemede gerekli değişiklikleri yapabileceği düzenlenmektedir. Buradan anlaşılması gereken husus hakimin, uygun görmediği düzenlemelere yönelik taraflara öneride bulunmasıdır. Hakim tarafından yapılan öneri eşler tarafından kabul edilirse boşanma kararı verilir. Aksi halde tarafların anlaşamadığı gerekçesi ile anlaşma temeline dayalı açılan boşanma davasının reddi gerekmektedir. Yargıtay'ın tutumu tarafların anlaşamaması halinde davanın evlilik birliğinin sarsılmasına dayalı (TMK md 166/I) boşanma davası olarak devam edilmesidir.

Hakimin yoksulluk nafakasına yönelik müdahalesinin kapsamı ve sınırlarını belirlemek açısından taraflarca kabul edilen düzenlemenin hukuki niteliğinin tayini önem arz etmektedir. Kanaatimiz, taraflarca kabul edilen düzenlemenin özel hukuk sözleşmesi olduğudur. Hakimin bu düzenlemeyi uygun bulma koşulu ise esasen sözleşmenin kurucu değil tamamlayıcı unsurudur. Sözleşme hakim tarafından onaylandıktan sonra da özel hukuk sözleşmesi niteliğini korumaktadır. Hakimin onayı ile sözleşmenin, mahkeme ilamının bir parçası olması da bu sonucu değiştirmemektedir. Maddi hukuka ilişkin sözleşme niteliğinde olan bu düzenlemelerin mahkeme içi sulh sözleşmesi karakteri taşıdığı sonucuna ulaşılmaktadır.

TMK md 166/III hükmünde hakimin, taraf menfaatlerini dikkate alarak düzenlemede değişiklik yapabileceği düzenlenmektedir. Madde metninde çocukların

\footnotetext{
35 Aynı yönde Ülkü Atmaca (n 17) 205. Nafaka miktarının taraf menfaatlerine uygun olup olmadığının belirlenmesi amacı ile ZGB Art 125 hükmüne paralel olarak tarafların bilgi ve belge getirme yükümlüğünün kabulü uygun olur. Zira tarafların mali ve ekonomik durumları bilinmeden tayin edilen nafaka miktarının hakkaniyetli olup olmadığı anlaşılamaz. "işste hakimin zorunlu ve çok önemli böyle bir görevi yerine getirebilmesi için, taraflarca hazırlanacak ayrıntıl anlaşmanın (yani) mali projenin mahkemeye sunulması veya tutanağa geçirilmiş olması kaçınılmazdır. Çünkü; eşlerin eksiksiz tüm malvarlıkları bilinmedikçe, taşınır ve taşınmaz malların ayrıntılı bir dökümü yapılmadıkça tarafların tekliflerinin ne ölçüde adil ve hakkaniyete uygun olduğunun belirlenmesi mümkün değildir." Yargitay 2 HD, 10499/14491, 21.11.1991 (Lexpera $<$ lexpera.com.tr> Erişim Tarihi 10 Eylül 2020).

136 Yargıtay 2 HD, 10499/14491, 21.11.1991 (Lexpera <lexpera.com.tr> Erişim Tarihi 10 Eylül 2020).
} 
durumuna ve boşanmanın mali sonuçlarına yönelik bir ayrım yapılmamakta ve hakimin denetim ödevinin kapsamı geniş tutulmaktadır. Bununla birlikte boşanma hukukuna ilişkin güncel yeni düzenlemeler ve olması gereken hukuk anlamında yaratılan prensiplerde ikili bir ayrım olduğu görülmektedir: Hakimin, çocuğun durumuna ilişkin düzenlemelere müdahalesinde takdir yetkisi geniş tutulurken boşanmanın mali sonuçlarına yönelik düzenlemelerde tarafların sözleşme özgürlüğü üstün tutulmaktadır. Avrupa Birliği Aile Hukukunu uyumlaştırma amacı ile ortaya konan prensipler de bu temel ayrım üzerine kurulmaktadır. Hakimin, çocuğun durumuna yönelik düzenlemeyi geçerlilik ve çocuğun yararına denetlemesi gerekliliği düzenlenirken mali sonuçların (en azından) geçerliliğine yönelik denetim ödevi işaret edilmektedir (PEFL 1:7 (1) ve (2)).

TMK md 166/IIIhükmünde bir ayrımyapılmamışolsa da taraflarınüzerinde serbestçe tasarruf edemeyeceği konulardan olan çocuğun durumuna ilişkin düzenlemeler konusunda hakimin müdahale yetkisinin kapsamı geniş değerlendirilmelidir. Ne var ki aynı sonuca boşanmanın mali sonuçları açısından varılamaz. Bu konularda tarafların sözleşme özgürlüğü çerçevesinde serbestçe aldıkları karara uyulması esastır. Bununla birlikte tarafların sözleşme özgürlüğünün sınırları mevcuttur ve bu sınırlar hakimin yoksulluk nafakasına yönelik müdahalesinin kapsamını belirlemektedir.

Hakim, yoksulluk nafakasına yönelik anlaşmada taraf iradelerinin sthhatli olup olmadığını denetlemelidir. TMK md 166/III hükmünde yer alan ve hakimin tarafları bizzat dinleyeceğini düzenleyen hüküm, hakimin boşanma ve boşanmanın sonuçlarına yönelik anlaşmanın serbest irade ürünü olup olmadığını incelemesini işaret eder. Tarafların serbest iradesinin ürünü olmayan anlaşmaların uygun görülmemesi ve anlaşma temeline dayalı açılan davanın reddi gereklidir.

Hakimin müdahalesi, bazen eksikliklerin tamamlanması yönünde öneri getirmek şeklinde olabilir. Tarafların yoksulluk nafakası yönünde sessiz kalması (düzenlemede yoksulluk nafakasına hiç yer verilmemiş olması) böyledir. Boşanmanın mali sonuçlarından olan yoksulluk nafakasına ilişsin anlaşmanın boşanmanın maddi şartı olması nedeniyle hakimin bu eksikliği tamamlatması gerekmektedir. Aynı durum tarafların yoksulluk nafakasını saklı tutmuş olması halinde de geçerlidir. Zira bu ihtimalde de taraflar, yoksulluk nafakasına ilişkin bir anlaşmaya varamamış ve nafakanın çözümünü boşanma davasından sonraya bırakmıştır. Nafaka hususunda bir anlaşmaya varılamamış olması nedeniyle hakimin bunu re'sen dikkate alması ve maddi şartın yerine getirilmesi amacı ile gerekli değişikliğin yapılması yönünde öneride bulunması gerekmektedir.

Tarafların, belirli bir miktar nafaka ödenmesi yönünde anlaşması; ancak nafakanın sonraki yıllardaki değişimine yönelik düzenleme yapmamış olması halinde kanaatimiz bu hali ile sözleşmenin onaylanabilir olduğu yönündedir. Nitekim TMK md 176/V 
hükmü uyarınca talebe bağlı olan bu husus, taraflarca kabul edilen düzenlemenin zorunlu unsurlarından değildir. Hakim; sadece düzenlemenin zorunlu olan unsurları (boşanmanın mali sonuçları ve çocuğun durumu) ile esasen ihtiyari olan; ancak taraflarca düzenlemeye dahil edilerek sübjektif esaslı unsur haline gelen unsurları denetlemekle yükümlüdür.

Tarafların nafakanın belirli süre ödeneceği yönünde anlaşması da mümkündür. Pozitif hukukumuzda nafakanın belirli süre için ödeneceği yönündeki anlaşmaların yasaklanmadığı; hatta çekişmeli boşanma davalarında taraflardan birinin süresiz olarak nafaka talep etmesi halinde dahi hakimin belirli süre nafakaya hükmetme yönünde takdir yetkisinin mevcut olduğu yönündeki görüş benimsenmektedir.

Taraflardan birinin yoksulluk nafakasından feragat etmesi halinde geçersizliğin sadece feragat iradesi yönünden değil TMK 23/I yönünden de yapılması gerekmektedir. Zira kişinin insan onuruna uygun ve elverişli şartlarda yaşamasını amaçlayan yoksulluk nafakasından feragati bazı durumlarda TMK md 23/I hükmüne aykırı olması nedeni ile geçersiz olabilir. Buna rağmen hakim tarafından uygun görülmesi de düzenlemeyi geçerli hale getirmez zira tamamlayıcı unsur olan hakim onayı geçerlilik şartlarını taşımayan bir sözleşmeye hüküm kazandırma işlevine sahip değildir. Bu kapsamda daha evvel feragat mevcut olmasına rağmen nafakanın sonradan talep edilmesi halinde taraflarca kabul edilen düzenlemenin TMK md 23 hükmü kapsamında geçerlilik denetiminin yapılması gerekmektedir.

Son olarak tarafların çok yüksek nafaka miktarı yönünde anlaşması halinde hakimin nafaka yükümlüsünün kişilik hakkına aykırı bir durum olup olmadığını incelemesi gerekmektedir. Aksine yükümlünün mali gücü yeterliyken nafaka alacaklısını yoksulluktan kurtarmayacak derecede az nafaka ödenmesi de TMK md 23 hükmüne aykırı olduğu müddetçe uygun bulunmamalıdır.

\footnotetext{
Hakem Değerlendirmesi: Dış bağımsız.

Çıkar Çatışması: Yazar çıkar çatışması bildirmemiştir.

Finansal Destek: Yazar bu çalışma için finansal destek almadığını beyan etmiştir.

Peer-review: Externally peer-reviewed.

Conflict of Interest: The author has no conflict of interest to declare.

Grant Support: The author declared that this study has received no financial support.
} 


\section{Bibliyografya/Bibliography}

Akıntürk T ve Ateş D, Türk Medeni Hukuku Aile Hukuku İkinci Cilt (Yenilenmiş 21. Bası, Beta, 2019). Arkan Serim A, 'Yoksulluk Nafakası' (2007) LXV (1) İ̈̈HFM 277-302.

Arsebük E, Medeni Hukuk II Aile Hukuku Kısım 1 (1940).

Atar E A, 'Nafakadan Feragat' (2016) 22 (3) MÜHFHAD Cevdet Yavuz'a Armağan 251-267.

Bauermann P, Grundlagen und Ausgestaltung im deutschen Unterhaltsrecht und in den Prinzipien der Commission on European Family Law (CEFL) (Stämpfli Verlag AG, 2013).

Beilfuss C G, 'CEFL’s Maintenance Principles: The Conditions For Maintenance' (2005) Common Core and Better Law in European Family Law 83-103.

Burcuoğlu H, 'Boşanmada Kusur ve Yoksulluk Nafakası ile İlgili Gözlemler' (2018) 4 (2) İstanbul Aydın Üniversitesi Hukuk Fakültesi Dergisi 1-12.

Bühler W ve Spühler K, Berner Kommentar, Die Ehescheidung, Art. 137-158 ZGB, Schweizerisches Zivilgesetzbuch, Das Familienrecht, Das Eherecht, (3. Bask1, Stämpfli Verlag AG, 1980).

Ceylan E, Türk ve İsviçre Hukukunda Boşanmanın Hukuki Sonuçları (Galatasaray Üniversitesi Yayınlar1, 2006).

Demir M, Türk Medeni Hukuk Öğreti ve Uygulamasında Yoksulluk Nafakası (Seçkin Yayıncılık, 2018).

Demirbaş A, ‘Güncel Tartışmalarla Yoksulluk Nafakası' (2018) 5 (2) İstanbul Medipol Üniversitesi Hukuk Fakültesi Dergisi 219-236.

Dural M, Öğüz T ve Gümüş M A, Türk Özel Hukuku Cilt III Aile Hukuku (Gözden Geçirilmiş 15. Bas1 Filiz Kitabevi, 2020).

Demirsatan B, 'Boşanmada Ev Hayvanlarının Hukuki Durumu' (2020) 24(3) Ankara Hacı Bayram Veli Üniversitesi Hukuk Fakültesi Dergisi 137-161.

Elçin Grassinger G, 'Boşanma Davasında Eşlerin Boşanmanın Tali Sonuçlarına İlişkin Konularda Anlaşma Yapmaları ve Konu ile İlgili İsviçre Federal Mahkemesi Kararı’ (1997) LV (3) İHFM 235-242.

Esener T, 'Boşanmanın Fer'i Neticelerine Dair Mukaveleler' (1951) VIII (3-4) AÜHFD 610-628.

Fankhauser R, Die Ehescheidung und die Ehetrennung / Erster Abschnitt: Die Scheidungsvoraussetzungen, FamKomm (3. Bask1, Stämpfli Verlag AG, 2017).

Ferrand F, 'Divorce and Spousal Agreements' (2005) Common Core and Better Law in European Family Law 71-83.

Freiburghaus D, Personen -und Familienrecht- Partnerschaftsgesetz Art.1-456 ZGB, Handkommentar zum Schweizer Privatrecht (3. Bask1, Schultess Juristische Medien AG, 2016).

Gençcan Ö U, 6100 sayılı HMK Hükümlerine Göre Boşanma, Tazminat ve Nafaka Hukuku (2. Bask1, Yetkin, 2013).

Helvacı S, Kişilik İşlemi Hakları (Münhasıran Şahsa Bağlı Haklar) (İstanbul Üniversitesi Sosyal Bilimler Enstitüsü, Yayımlanmamış Doktora Tezi, 1993).

Hoşlan Ö C, 'Anlaşmalı Boşanma Protokollerine İlişkin Yargıtay Kararlarının Değerlendirilmesi' Medeni Hukuk Alanındaki Güncel Yargıtay Kararlarının Değerlendirilmesi Sempozyumları, Cilt II: Aile Hukuku (On iki Levha, 2019) 203-285.

Jungo A, Personen- und Familienrecht - Partnerschaftsgesetz Art. 1-456 ZGB - PartG, Handkommentar zum Schweizer Privatrecht (3. Bask1, Schulthess Juristische Medien AG, 2016). 
Kırbaş Ö, Türk Hukuku'nda Eşlerin Anlaşmasına Dayanan Boşanma: (MK.m.134/III), (İstanbul Üniversitesi Sosyal Bilimler Enstitüsü, Yayımlanmamış Yüksek Lisans Tezi, 1994).

Kocabaş G, 'Evlilik Sonrası Dayanışma İlkesi ve Bu İlkenin Sınırı Olarak Clean Break İlkesi Doğrultusunda Yoksulluk Nafakasını Belirleyici Ölçütler' (2013) 19 (1) 357-392.

Kulaklı E, 'Yoksulluk Nafakası ve Yoksulluk Nafakasının Süresi Bağlamında Bir Mukayeseli Hukuk İncelemesi' (2018) 5 (2) İstanbul Medipol Üniversitesi Hukuk Fakültesi Dergisi 237-268.

Nomer H N, Borçlar Hukuku Genel Hükümler (Gözden Geçirilmiş, Genişletilmiş Ondördüncü Bask1, Beta, 2015).

Oğuzman M K ve Öz T, Borçlar Hukuku Genel Hükümler Cilt-1 (Güncellenip Genişletilmiş 17. Bası Vedat Kitapçılık, 2019).

Oktay Özdemir S, "Sözleşme Özgürlüğü” (2019) 1 İstanbul Şerhi Türk Borçlar Kanunu: Yürürlük Kanunu Madde 1-82, 337-441.

Oktay Özdemir S, ‘Türk Hukukunda Boşanma Sisteminde Revizyon İhtiyacı' (2015) 35 (1) MHB 29-46.

Özdemir N, Türk Hukukunda Anlaşmalı Boşanma (İstanbul Üniversitesi Sosyal Bilimler Enstitüsü, Yayımlanmamış Doktora Tezi, 2003).

Özer M T, Medeni Hukukta Hata Kavramı (On iki Levha, 2019).

Öztan B, Aile Hukuku (6. Bas1, Turhan Kitabevi, 2015).

Roth M, 'Future Divorce Law- Two Types of Divorce' (2005) Common Core and Better Law in European Family Law 41-58.

Ruhi A C, Yargıtay İçtihatlarıyla Nafaka Hukuku (3. Baskı, 2010).

Schwander I, ZGB 125, OFK-Orell Füssli Kommentar (Gözden Geçirilmiş 3. Bask1, Orell Füssli Verlag AG, 2016).

Schwenzer I ve Büchler A, Dritte Abschnitt: Die Scheidungsfolgen/ Art. 125/I.-II., FamKomm (3. Bask1, Stämpfli Verlag, 2017).

Seçer Ö, 'Anlaşmalı Boşanmada Eşlerin Yaptıkları Anlaşma' (2016) 7 (2) İnönü Üniversitesi Hukuk Fakültesi Dergisi) 259-286.

Shannon G, 'Clean Break or Long-Term Payment of Maintenance' (2005) Common Core and Better Law in European Family Law 103-119.

Şahin M, 'Türk-İsviçre Medeni Kanunlarına Göre Evlilik Sonrası Katkının (Yoksulluk Nafakasının) Şartları (TMK m.175-ZGB m.125)' (2017) XXI (3) Gazi Üniversitesi Hukuk Fakültesi Dergisi 75-107.

Şıpka Ş, ‘Avrupa Birliği Aile Hukuku ve CEFL (Avrupa Birliği Aile Hukuku Komisyonu, Prensipleri, Amaçları ve Yapılan Çalışmalar)' (2006) 10 (2) 163-172.

Tekinay S S, Türk Aile Hukuku (7. Bask1, Filiz Kitavevi, 1990).

Uzun M, Yargıtay Kararları Kapsamında Yoksulluk Nafakası (Vedat Kitapçı1ık, 2013).

Ülkü Atmaca H, Türk Hukukunda Anlaşmalı Boşanma Protokolü (Yeditepe Üniversitesi Sosyal Bilimler Enstitüsü, Yayımlanmamış Doktora Tezi, 2017).

Yağcı K, 'Yoksulluk Nafakasında Süresizlik Sorunu' (2018) 76 (1) İstanbul Hukuk Mecmuası 323-358.

Yıldırım A, 'Yoksulluk Nafakası ve Yoksulluk Nafakasında Süre Sorunu' (2016) 14 (157) 59-89.

Yücedağ N, 'Kadının Talep Ettiği Yoksulluk Nafakası' (2017) 6. Uluslararası Suç ve Ceza Film Festivali 509-529.

Yücel S, 'Yargıtay Kararları Işığında Anlaşmalı Boşanma Davası Sonrasında Nafaka ve Tazminat Talepleri' (2018) 4 (1) 239-257. 